\title{
Groundwater and nutrient discharge through karstic coastal springs (Castelló, Spain)
}

\author{
E. Garcia-Solsona ${ }^{1}$, J. Garcia-Orellana ${ }^{1}$, P. Masqué1 ${ }^{1}$, V. Rodellas ${ }^{1}$, M. Mejías ${ }^{2}$, B. Ballesteros ${ }^{2}$, and J. A. Domínguez ${ }^{2}$ \\ ${ }^{1}$ Institut de Ciència i Tecnologia Ambientals (ICTA)-Departament de Física, Universitat Autònoma de Barcelona, 08193, \\ Cerdanyola del Vallès, Spain \\ ${ }^{2}$ Geological Survey of Spain (IGME), Ríos Rosas, 23, 28003 Madrid, Spain
}

Received: 7 January 2010 - Published in Biogeosciences Discuss.: 26 January 2010

Revised: 23 August 2010 - Accepted: 28 August 2010 - Published: 7 September 2010

\begin{abstract}
Discharge of groundwater and associated chemical compounds into coastal karstic regions, which are abundant in the Mediterranean basin, is envisaged to be significant. In this study, we evaluate the groundwater discharge and its nutrient load to the open karstic site of Badum (Castelló, East Spain). Salinity profiles evidenced that groundwater discharge from coastal brackish springs causes a buoyant fresher layer, as identified with thermal infrared images. Chemical tracers (radium isotopes, dissolved inorganic silicate and seawater major elements) have been used to determine a brackish groundwater proportion in coastal waters of 36\% in October 2006 and 44\% in June 2007. Based on a radium-derived residence time of 2.7 days in October 2006 and 2.0 days in June 2007, total SGD fluxes have been estimated in 71500 and $187000 \mathrm{~m}^{3} \mathrm{~d}^{-1}$, respectively, with fresh-SGD contributions representing $71 \%$ and $85 \%$. The calculated SGD-associated nutrient fluxes, most likely of natural origin, were 1500 and $8300 \mu \mathrm{mol} \mathrm{m}^{-2} \mathrm{~d}^{-1}$ of DIN and 19 and $40 \mu \mathrm{mol} \mathrm{m}^{-2} \mathrm{~d}^{-1}$ of DIP in October 2006 and June 2007 , respectively. These inputs may actually lead to or enhance $\mathrm{P}$ limitation, thereby altering the structure of biological communities in the area.
\end{abstract}

\section{Introduction}

All aquifers with a hydraulic connection to the sea may discharge to coastal environments (Burnett et al., 2003) and are susceptible to seawater intrusion (Bear et al., 1999). Indeed, early studies by Cooper (1959) and Kohout (1960) already recognized that the freshwater-seawater interface was not as

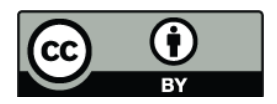

Correspondence to: E. Garcia-Solsona (esther.garcia@uab.es) abrupt as delineated by the Ghyben - Herzberg principle, but formed a region of mixed water composition termed as a "mixing zone" of fresh and saline waters (Price and Herman, 1991). Many aquifers are conformed by detritic materials where the discharge seepage is produced by diffusive processes, and seawater recirculation through the sediments may constitute a major component of submarine groundwater discharge (SGD) (Burnett et al., 2006). Conversely, in karst geological formations, fresh groundwater is channelized through preferential pathways created from limestone dissolution, being the main constituent when discharging to the sea. In the coastal zone of the Mediterranean basin there are very heterogeneous and disrupted mountain chains, some of them with extended development of carbonate formations (especially limestones and dolomites) that are responsible for the creation of karst configurations. In fact, Mediterranean karstic areas border $60 \%$ of the coastline and are estimated to contribute around $75 \%$ of the total freshwater input to the sea: much of it must be via SGD (UNESCO, 2004). In the Mediterranean Sea, a widespread existence of SGD via submarine springs has been identified along the coasts of Turkey, Syria, Lebanon, Israel, Greece, Italy, France, Spain, Algeria, Tunisia, Libya (Mijatovic, 2007). However, there are only a few local or regional studies on the quantification of karstic SGD fluxes in the Mediterranean carbonate basin, carried out in coastal areas of Italy (Moore, 2006a), Turkey (Bakalowicz et al., 2008), Israel (Swarzenski et al., 2006) and Spain (Garcia-Solsona et al., 2010).

SGD is a potential source of chemical compounds, such as nutrients, metals and pollutants, which may impact the ecology of these coastal systems. The transfer of these substances to coastal areas via SGD has been recognized of enormous significance since these fluxes may modify biogeochemical cycles (Boehm et al., 2004; Corbett et al., 2000;

Published by Copernicus Publications on behalf of the European Geosciences Union. 
Moore, 1996; Paytan et al., 2006) and could alter the ecological status of the water bodies. For example, dissolved nutrient inputs through SGD, which may have both natural and anthropogenic origins, have been shown to be a factor in algal growth dynamics (Johannes, 1980; Kinney and Roman, 1998; Sewell, 1982), ecological modification of coastal ecosystems (McClelland et al., 1997; Short and Burdick, 1996; Valiela et al., 1992) and eutrophication processes including harmful algal blooms (Basterretxea et al., 2009; Giblin and Gaines, 1990; Gobler and Sañudo-Wilhelmy, 2001; Laroche et al., 1997). Among these nutrients, nitrogen is particularly important because represents a limiting nutrient for primary production in most of the world's oceans (Borum, 1996; Nixon and Pilson, 1983). However, the Mediterranean is considered to be P limited (Krom et al., 1991).

Karstic formations are highly susceptible to be contaminated from urban, industrial and agricultural wastewaters (Tapia González et al., 2008) and may constitute a rapid pathway of nutrients and pollutants to the sea due to the low filtration in the aquifer. The groundwater dynamics in karst regions leads the coupled coastal ecosystems to be particularly vulnerable to ecological disturbances (Young et al., 2008). In addition, the Mediterranean basin is affected by an intense demand of its water resources due to the increase of population and tourism. Then, the contamination of its aquifers, and especially the karstic ones, could represent an important concern to be addressed in water resource management. Like the SGD water fluxes, the analyses of nutrient discharges throughout this pathway in Mediterranean karstic formations are scarce, though required to establish the ecological status of the aquifers and the coastal environments. For example, phytoplankton and harmful algal blooms (HABs) are frequent in Mediterranean coastal regions (Basterretxea et al., 2005; Garcés et al., 1999; Giacobbe et al., 2007; Honsell et al., 1995; Vila et al., 2001) and there are insufficient studies evaluating the potential SGD role in such phenomena (Garcia-Solsona et al., 2010).

Over the last 15 years, several techniques have been used to estimate submarine groundwater discharge fluxes to coastal areas. One of the successful tools to evaluate the total SGD (fresh groundwater plus recirculated seawater) is the radium isotopic quartet $\left({ }^{223,224,226,228} \mathrm{Ra}\right)$. The approach is based on the groundwater enrichment in radium and the detection of the excess radium in coastal waters (Moore, 1996). In addition, coastal waters residence times can also be derived from radium isotopes owing to their different halflives ( $3.7 \mathrm{~d}$ for ${ }^{224} \mathrm{Ra}, 11.4 \mathrm{~d}$ for ${ }^{223} \mathrm{Ra}, 5.75 \mathrm{y}$ for ${ }^{228} \mathrm{Ra}$ and $1,600 \mathrm{y}$ for $\left.{ }^{226} \mathrm{Ra}\right)$. On the other hand, other elements may be enough enriched or diluted in groundwater (e.g. dissolved inorganic silicate-Hwang et al., 2005a - and seawater major elements, respectively) that enable us to estimate the groundwater fraction in coastal waters.

The aim of this study is to determine the proportion of karstic springs' groundwater in the Badum coastal area (Peníscola, Castelló), at the eastern Spanish Mediterranean

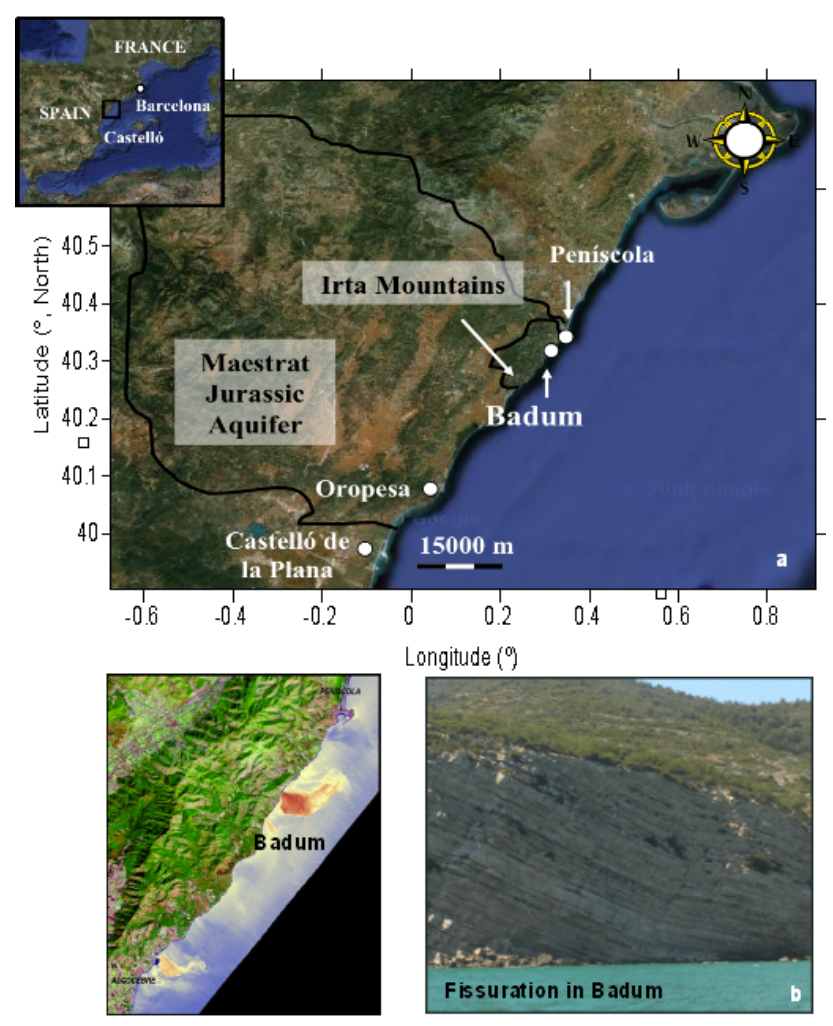

Fig. 1. (a) Location map of the Badum coastal area, which resides inside a natural protected region (Irta Mountains). The extension of the main carbonate Maestrat aquifer is also delimited.). (b) Thermal infrared image of the area taken on June 2006 (from Antón-Pacheco et al., 2007) (left) and (b) a picture of the Badum coastal area showing the rock fissuration of the karstified Maestrat aquifer that allows coastal springs to occur (right).

coastline, by mass balances of (i) radium isotopes, (ii) dissolved inorganic silicate and (iii) seawater major elements. Radium isotopes will be then used to estimate the water residence time and the total SGD flux. Also, we endeavor to quantify the input of dissolved inorganic nutrients via SGD in order to advance in the understanding of the ecological status in the area.

\section{Study area}

The Badum study site, in Peníscola (Castelló, Spain), is an open coastal area corresponding to a well developed karstic structure with high permeability by fissuration and karstification processes (Mejías et al., 2008). The geologic formation that constitutes the littoral aquifer sits at grand depths (Jurassic aquifer of El Maestrat) but it outcrops in the proximity of the coast. The aquifer conditions are excellent near the shoreline, with transmissivity ranging from 1000 to $4000 \mathrm{~m}^{2} \mathrm{~d}^{-1}$ (Ballesteros, 1989) and average exploitation rates between 50 and $100 \mathrm{~L} \mathrm{~s}^{-1}$. A mathematical model developed for the Irta Mountains area (Fig. 1) 


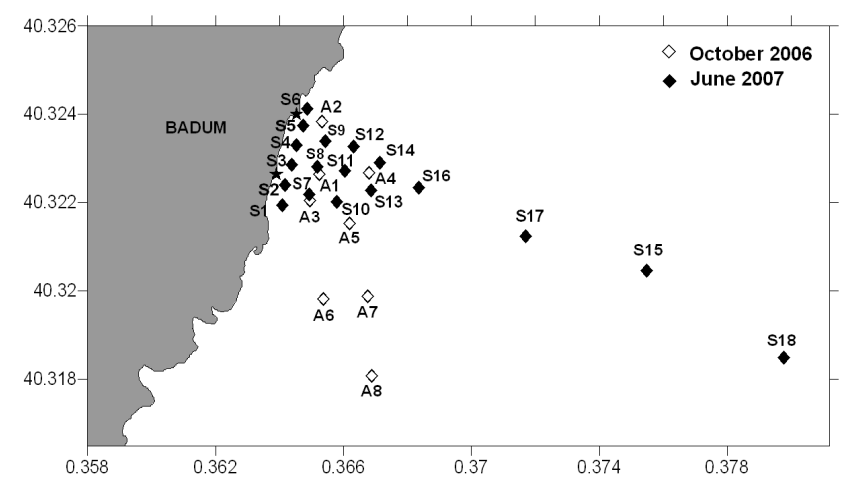

Fig. 2. Water stations in the Badum coastal area corresponding to October 2006 (open squares) and June 2007 samplings (solid squares). The stars indicate the sampled coastal springs.

(Serrano et al., 1995) showed even higher transmissivity values (from 9000 to $15000 \mathrm{~m}^{2} \mathrm{~d}^{-1}$ ), consistent with the strong karstification that presents the aquifer in that region.

Annual precipitation typically ranges from $400-650 \mathrm{~mm}$, with wet and dry seasons characteristic of the Mediterranean regions. As many other karstic areas, precipitation penetrates the ground resulting in negligible surface runoff (excepting in cases of torrential runoff) and no permanent rivers in the area. The immediate seabed of the coastal aquifer is basically composed of coarse sands since the absence of rivers prevents the arrival of fine sediments in the vicinity. Also, strong winds support coastal waters mixing with open sea at short time scales.

Hydrological models were used to provide first estimates of SGD from coastal springs of the Irta Mountains, obtaining fluxes in the range of $80-175 \times 10^{6} \mathrm{~m}^{3} \mathrm{y}^{-1}$ (Ballesteros, 1989; IGME, 1988; IGME-IRYDA, 1977). Subsequent studies, based on a reinterpretation of the geological model, research drillings (Serrano et al., 1995) and a mathematical modeling of the coastal aquifer sector, refined the estimation of the groundwater discharge in $64 \times 10^{6} \mathrm{~m}^{3} \mathrm{y}^{-1}$.

The deep Maestrat Jurassic aquifer is the single hydrogeological region potentially contributing groundwater discharge to the Irta Mountains shoreline, i.e., through the coastal springs identified in Alcossebre, Peníscola and Badum. Thermal infrared aerial images allowed identifying Badum as the main area affected by SGD from coastal springs (Fig. 1; Antón-Pacheco et al., 2007).

\section{Sampling and methods}

Two sampling surveys at Badum coastal area were carried out in October 2006 and June 2007 (Fig. 2). Water samples were obtained for Ra isotopes $\left({ }^{223} \mathrm{Ra},{ }^{224} \mathrm{Ra},{ }^{226} \mathrm{Ra}\right.$ and $\left.{ }^{228} \mathrm{Ra}\right)(50 \mathrm{~L})$, dissolved inorganic nutrients $\left(\mathrm{PO}_{4}^{3-}, \mathrm{NH}_{4}^{+}\right.$, $\mathrm{NO}_{2}^{-}, \mathrm{NO}_{3}^{-}$and $\left.\mathrm{SIO}_{4}^{2-}\right)(60 \mathrm{~mL})$ and dissolved major elements ( $\mathrm{S}, \mathrm{Cl}, \mathrm{K}, \mathrm{Ca}, \mathrm{Br}, \mathrm{Sr}$ and $\mathrm{Ba})(60 \mathrm{~mL})$. All water sam- ples were collected at $20 \mathrm{~cm}$ depth, plus three stations also sampled at $50 \mathrm{~cm}$ depth. Temperature and salinity profiles with depth were also obtained from several stations using a portable salinometer (YSI 660XLM).

Groundwater from two coastal brackish springs was also collected with a small submersible pump ( $\sim 25 \mathrm{~L})$ during both surveys. In addition, one of these springs (SP1) was monitored monthly from March 2007 to February 2008, measuring salinity, temperature, $\mathrm{Ra}$ and nutrients.

The radium isotopes were extracted from water samples using acrylic fiber impregnated with manganese oxide (Mnfiber). The water samples were passed in the field through columns (at $<1 \mathrm{~L} \mathrm{~min}^{-1}$ ) containing Mn-fiber (25 g-dry), which quantitatively removed the radium (Moore, 1976). A Radium Delayed Coincidence Counter (RaDeCC) was used to determine the short-lived radium activities, ${ }^{223} \mathrm{Ra}$ and ${ }^{224} \mathrm{Ra}$ (Moore and Arnold, 1996), and their associated uncertainties were calculated following Garcia-Solsona et al. (2008). Activities of the long-lived isotopes, ${ }^{226} \mathrm{Ra}$ and ${ }^{228} \mathrm{Ra}$, were determined by measuring the ashed Mn-fibers with a well-shaped germanium gamma detector (Charette et al., 2001).

Dissolved inorganic nutrients were collected in polypropylene bottles and kept frozen until analysis, which were carried out using an auto-analyzer (Grasshoff et al., 1999). For this study, DIN is defined as the sum of $\mathrm{NO}_{3}^{-}, \mathrm{NO}_{2}^{-}$and $\mathrm{NH}_{4}^{+}$, DIP as $\mathrm{PO}_{4}^{3-}$ and $\mathrm{DSi}$ as $\mathrm{SiO}_{4}$. Water for the determination of major elements $(\mathrm{S}, \mathrm{Cl}, \mathrm{K}, \mathrm{Ca}, \mathrm{Br}$ and $\mathrm{Sr}$ ) was sampled in the same way and analyzed by $\mathrm{X}$-Ray fluorescence.

\section{Results}

\subsection{Salinity and radium distribution}

The thermal infrared image taken in June 2006 (Fig. 1) showed the existence of a plume of colder water moving offshore from identified coastal springs (total shoreline of aprox. $600 \mathrm{~m}$ long). This observation was confirmed by the temperature and salinity measurements during both sampling campaigns (Table 1). Surface water salinities in the autumn and summer periods ranged from 23.5 to 33.0 and from 14.5 to 37.0 , respectively. The high salinities at stations A7 (38.2) in autumn and S16 (37.8) in summer indicated that they were out of the fresher plume. A strong salinity and temperature vertical stratification was observed in June 2007 from water column profiles carried out at stations S11 and S16 (150 m and $350 \mathrm{~m}$ offshore, respectively). This fresher layer corresponds to the SGD plume moving offshore and forming a layer of 40 centimeters thickness (Fig. 3).

Surface radium activities in coastal waters are given in Table 1. On average, radium activities in October 2006 sampling were slightly higher than in June 2007 (1.2-1.4 times). The highest salinity samples (A7 and S16, in October and 
Table 1. Temperature, salinity, radium activities and nutrient concentrations for all the stations samples in October 2006 and June 2007.

\begin{tabular}{|c|c|c|c|c|c|c|c|c|c|}
\hline \multirow{2}{*}{$\begin{array}{l}\text { Station } \\
\text { number }\end{array}$} & \multirow{2}{*}{$\begin{array}{c}T \\
\left({ }^{\circ} \mathrm{C}\right)\end{array}$} & \multirow[t]{2}{*}{ Sal } & \multicolumn{4}{|c|}{ Ra activity (dpm $\left.100 \mathrm{~L}^{-1}\right)$} & \multicolumn{3}{|c|}{ Nutrient concentration $(\mu \mathrm{M})$} \\
\hline & & & ${ }^{223} \mathrm{Ra}$ & ${ }^{224} \mathrm{Ra}$ & ${ }^{226} \mathrm{Ra}$ & ${ }^{228} \mathrm{Ra}$ & DIN & DIP & $\mathrm{DSi}$ \\
\hline \multicolumn{10}{|c|}{ October sampling $(24 / 10 / 2006)$} \\
\hline \multicolumn{10}{|c|}{ Surface coastal waters } \\
\hline A1 & 20.4 & 27.1 & $10.1 \pm 1.1$ & $111 \pm 7$ & $130 \pm 2$ & $91 \pm 2$ & 23.8 & 0.13 & 25.3 \\
\hline $\mathrm{A} 2$ & 20.2 & 25.3 & $10.2 \pm 1.7$ & $132 \pm 7$ & $142 \pm 2$ & $100 \pm 2$ & 37.6 & 0.17 & 32.7 \\
\hline A3 & 20.0 & 23.5 & $10.5 \pm 0.8$ & $156 \pm 7$ & $142 \pm 6$ & $114 \pm 3$ & 34.5 & 0.18 & 35.7 \\
\hline A4 & 21.1 & 30.2 & $7.6 \pm 0.9$ & $90 \pm 6$ & $104 \pm 5$ & $69 \pm 2$ & 20.8 & 0.11 & 18.6 \\
\hline A5 & 20.8 & 28.6 & $8.1 \pm 1.4$ & $105 \pm 5$ & $121 \pm 5$ & $87 \pm 2$ & 24.9 & 0.13 & 19.2 \\
\hline A6 & 21.3 & 32.0 & $4.6 \pm 0.5$ & $76 \pm 3$ & $87 \pm 4$ & $57 \pm 2$ & 26.4 & 0.11 & 14.2 \\
\hline A8 & 21.3 & 33.0 & $4.4 \pm 0.4$ & $73 \pm 3$ & $71 \pm 3$ & $50 \pm 2$ & 28.2 & 0.08 & 13.1 \\
\hline \multicolumn{10}{|c|}{ Average coastal waters } \\
\hline & 20.7 & 28.5 & $8 \pm 2$ & $106 \pm 30$ & $114 \pm 27$ & $81 \pm 23$ & 28.0 & 0.13 & 22.7 \\
\hline \multicolumn{10}{|l|}{ Springs } \\
\hline A-SP1 & 19.4 & 13.7 & $13.2 \pm 1.2$ & $227 \pm 11$ & $254 \pm 2$ & $185 \pm 4$ & 28.5 & 0.36 & 66.2 \\
\hline A-SP2 & 19.1 & 8.7 & $21.5 \pm 1.6$ & $253 \pm 12$ & $261.5 \pm 1.7$ & $212 \pm 4$ & & & \\
\hline
\end{tabular}

Seawater: out of the fresher plume water

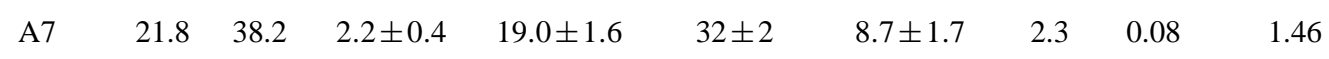

June Sampling (4-6/06/2007)

Surface coastal waters

$\begin{array}{cccccccccc}\text { S1 } & 20.1 & 28.3 & 4.8 \pm 0.3 & 54 \pm 2 & 64.9 \pm 1.4 & 42.8 \pm 1.7 & 24.2 & 0.29 & 20.8 \\ \text { S2 } & 21.2 & 32.2 & 3.8 \pm 0.2 & 53.3 \pm 1.8 & 52 \pm 2 & 34.4 \pm 1.7 & 19.6 & 0.39 & 13.5 \\ \text { S3 } & 20.1 & 18.9 & 6.2 \pm 0.7 & 98 \pm 3 & 119 \pm 5 & 87 \pm 3 & 38.1 & 0.34 & 21.1 \\ \text { S4 } & 21.7 & 28.0 & 4.7 \pm 1.1 & 63 \pm 9 & 73 \pm 3 & 56.2 \pm 1.9 & 20.8 & 0.44 & 16.8 \\ \text { S5 } & 21.8 & 33.8 & 2.8 \pm 0.2 & 32 \pm 2 & 37.8 \pm 1.8 & 25.6 \pm 1.1 & 13.7 & 0.35 & 10.6 \\ \text { S6b } & 19.0 & 16.8 & 5.1 \pm 0.6 & 124 \pm 4 & 137 \pm 6 & 104 \pm 3 & 56.3 & 0.39 & 36.6 \\ \text { S7 } & 19.8 & 26.9 & 4.1 \pm 1.0 & 74 \pm 10 & 63.8 \pm 1.5 & 46.3 \pm 1.7 & 34.2 & 0.38 & 30.7 \\ \text { S8 } & 19.1 & 21.7 & 6.0 \pm 0.4 & 95 \pm 3 & 113.2 \pm 1.8 & 79.6 \pm 1.7 & 50.9 & 0.4 & 36.8 \\ \text { S9 } & 19.5 & 16.6 & 8.8 \pm 0.5 & 108 \pm 4 & 118 \pm 6 & 96 \pm 3 & 69.6 & 0.44 & 46.6 \\ \text { S10 } & 19.2 & 22.3 & 6.1 \pm 0.7 & 80 \pm 3 & 109 \pm 5 & 79 \pm 2 & 46.3 & 0.36 & 32.9 \\ \text { S11 } & 19.1 & 21.0 & 7.2 \pm 1.8 & 92 \pm 13 & 77.7 \pm 1.7 & 74 \pm 3 & 50.8 & 0.39 & 35.7 \\ \text { S12 } & 19.6 & 27.7 & 4.4 \pm 0.4 & 57 \pm 2 & 55 \pm 3 & 58 \pm 3 & 32.1 & 0.34 & 26.1 \\ \text { S13 } & 19.0 & 19.3 & 7.0 \pm 0.4 & 117 \pm 3 & 119 \pm 5 & 91 \pm 2 & 44.1 & 0.37 & 31.8 \\ \text { S14 } & 18.8 & 14.5 & 8.7 \pm 1.0 & 127 \pm 4 & 154 \pm 7 & 105 \pm 3 & 59.5 & 0.43 & 42.9 \\ \text { S15 } & 20.9 & 37.0 & 1.6 \pm 0.4 & 23 \pm 7 & 20.5 \pm 1.3 & 15.0 \pm 1.5 & 7.3 & 0.23 & 3.2 \\ \text { S17 } & 21.4 & 27.0 & 4.2 \pm 0.3 & 67 \pm 2 & 66.0 \pm 1.2 & 49.7 \pm 1.2 & 27.3 & 0.27 & 22.9 \\ \text { S18 } & 20.2 & 23.3 & 4.9 \pm 0.3 & 96 \pm 3 & 75.5 \pm 1.8 & 66 \pm 2 & 38.7 & 0.32 & 28.3\end{array}$

Average coastal waters

$\begin{array}{lllllllll}20.0 & 24.4 & 6 \pm 2 & 86 \pm 40 & 85 \pm 40 & 63 \pm 29 & 37.3 & 0.36 & 26.9\end{array}$

Coastal waters at $50 \mathrm{~cm}$ depth

\begin{tabular}{cccccccccc} 
S8 -50 & 36.3 & 20.4 & $2.5 \pm 0.3$ & $32.3 \pm 1.3$ & $22.1 \pm 1.6$ & $15.0 \pm 1.4$ & 10.4 & 0.27 & 8.1 \\
S11-50 & 36.0 & 20.6 & $2.3 \pm 0.2$ & $29.9 \pm 1.0$ & $25.0 \pm 0.7$ & $16.1 \pm 1.0$ & 9.0 & 0.25 & 9.6 \\
S13-50 & 36.0 & 21.1 & $2.2 \pm 0.2$ & $31.0 \pm 1.1$ & $23.1 \pm 0.7$ & $14.8 \pm 1.0$ & 9.6 & 0.26 & 5.5 \\
Springs & & & & & & & & \\
S-SP1 & 18.4 & 5.5 & $9.6 \pm 1.3$ & $158 \pm 8$ & $189 \pm 9$ & $140 \pm 4$ & 114.1 & 0.53 & 57.1 \\
S-SP2 & 18.2 & 5.5 & $3.1 \pm 1.0$ & $175 \pm 25$ & $157 \pm 3$ & $139 \pm 5$ & 74.7 & 0.38 & 36.2 \\
Seawater: out of the fresher plume water \\
\multicolumn{7}{l}{ S16 } \\
\hline
\end{tabular}




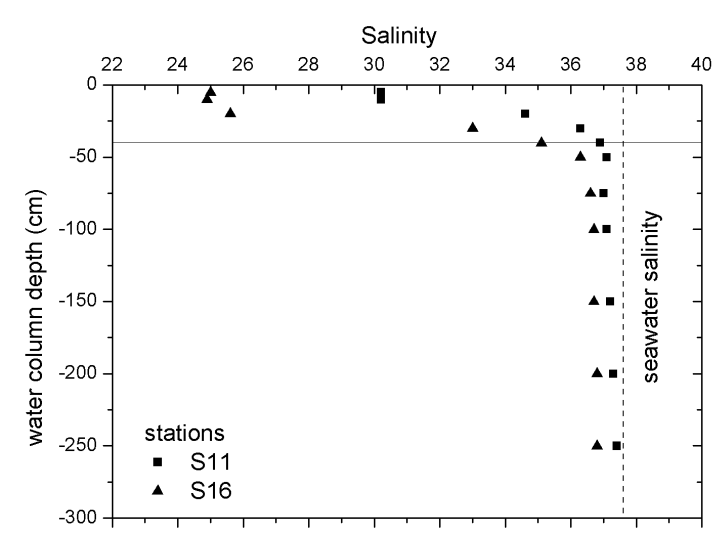

Fig. 3. Salinity profiles evidencing a fresher, less dense layer of $40 \mathrm{~cm}$ in June 2007.

June respectively) showed significantly lower radium activities, indicating a minimal influence of SGD.

${ }^{223} \mathrm{Ra}$ and ${ }^{224} \mathrm{Ra}$ activities in spring's groundwater averaged 17 and $240 \mathrm{dpm} \mathrm{100L}^{-1}$ (October 2006) and 6 and $166 \mathrm{dpm} \mathrm{100L}^{-1}$ (June 2007), respectively, thus evidencing a clear radium enrichment in comparison with surface waters ${ }^{223} \mathrm{Ra}$ and ${ }^{224} \mathrm{Ra}$ activities (averages of 8 and

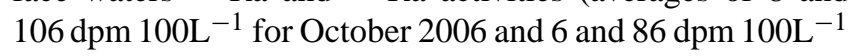
for June 2007, respectively) (Table 1 and 2). The highest activities in these brackish coastal springs were measured in spring and autumn. Monthly salinities within the springs ranged from 5.0 to 13.7 (Tables 1 and 2).

Positive linear correlations among radium isotopes in all surface samples are observed, pointing to coastal sea and the brackish springs as the endmembers (Fig. 4). The same pattern is shown for Ra activities and salinity (Fig. 5), with linear correspondences pointing to the brackish springs as the main contributor of radium.

\subsection{Nutrients}

Concentrations of dissolved inorganic nutrients in all the stations are summarized in Table 1 . Concentrations of $\mathrm{NO}_{3}^{-}$, DIP and DSi, were significantly elevated in the fresher surface waters relative to the waters at $50 \mathrm{~cm}$ depth (t-test $p<0.003,<0.001$ and $<0.0001$, respectively; Table 1 ). In contrast, $\mathrm{NH}_{4}^{+}$was higher below the fresher layer and $\mathrm{NO}_{2}^{-}$ showed no clear trends with either salinity or depth. Our data can be compared to nutrient measurements in the NW Mediterranean Sea platform areas, either influenced or not by riverine inputs of nutrients (Segura, 2007): DIP concentrations in our study were lower than average concentrations in surface waters in the continental shelf of the NW Mediterranean Sea $(0.37 \mu \mathrm{M})$. Dissolved $\mathrm{NO}_{3}, \mathrm{NH}_{4}$ and DSi concentrations were higher than in surface waters in the continental shelves $(0.95,1.00$ and $5.00 \mu \mathrm{M}$, respectively).

The concentrations of DIN and DSi in October 2006 vs. June 2007 were not statistically different (t-test $p<0.064$ and
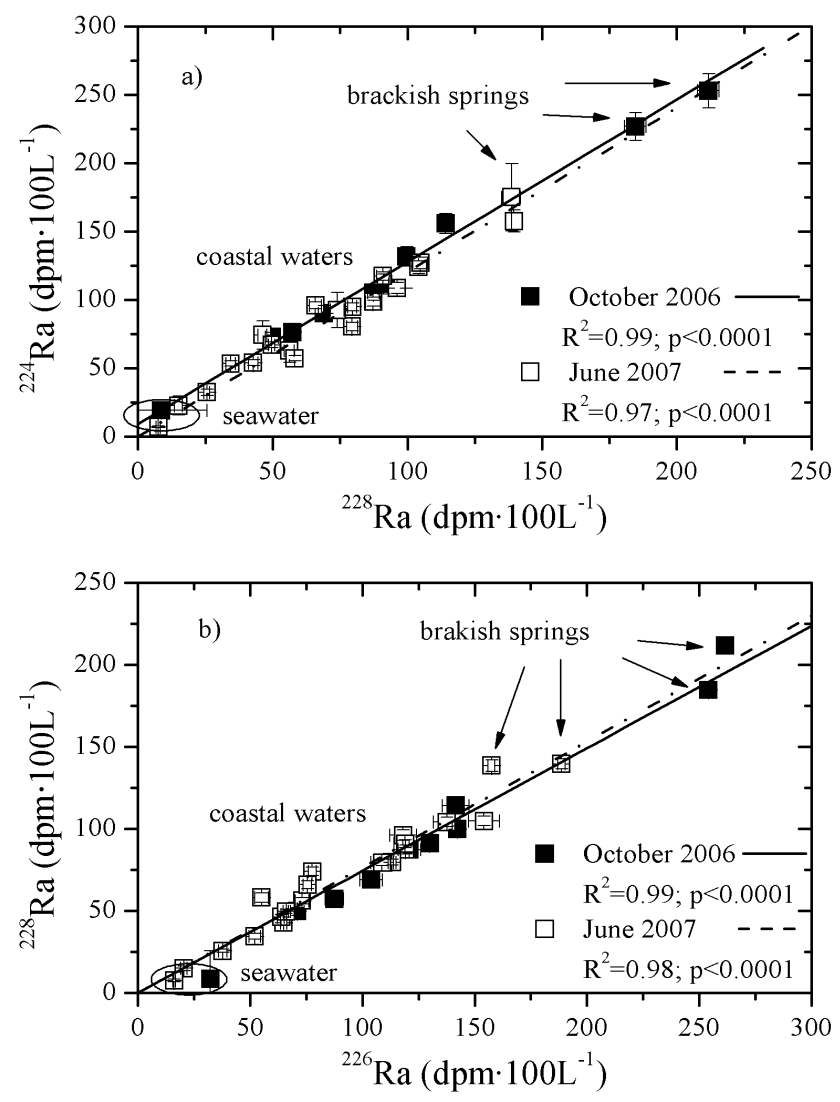

Fig. 4. ${ }^{224}$ Ra vs. ${ }^{228} \mathrm{Ra}$ (a) and ${ }^{228} \mathrm{Ra}$ vs. ${ }^{226} \mathrm{Ra}$ (b) plots for surface coastal waters, seawater and coastal springs. The significant positive linear correlations among them suggest surface waters are affected by binary mixing between seawater and spring groundwater.

$<0.352$, respectively), unlike DIP, which was significantly higher in June 2007 than in October $2006\left(p<10^{-10}\right)$. DIP was correlated with surface radium activities in October 2006 $\left(R^{2}=0.77-0.86\right)$, but less so in June $2007\left(R^{2}=0.54-0.68\right)$. Conversely, we only observed significant correlations of DIN and $\mathrm{Ra}$ during June $2007\left(R^{2}=0.92-0.95\right)$. DSi concentrations and all radium isotopes in surface waters showed significant positive correlations (Fig. 6) during both sampling periods, pointing to a conservative behavior of DSi in these coastal waters. This confirms the potential of DSi as a tracer of SGD (Hwang et al., 2005a, b).

\subsection{Major elements in seawater}

Concentrations of major elements in samples A7 and S16 (located out of the fresher water plume) are typical of seawater (Moe, 1982). Significant negative linear correlations of $\mathrm{Cl}, \mathrm{S}, \mathrm{Ca}, \mathrm{K}, \mathrm{Br}$ and $\mathrm{Sr}$ with radium isotopes and salinity were obtained (Fig. 7), indicating conservative behavior of major elements in seawater when diluted by spring groundwater discharge. 

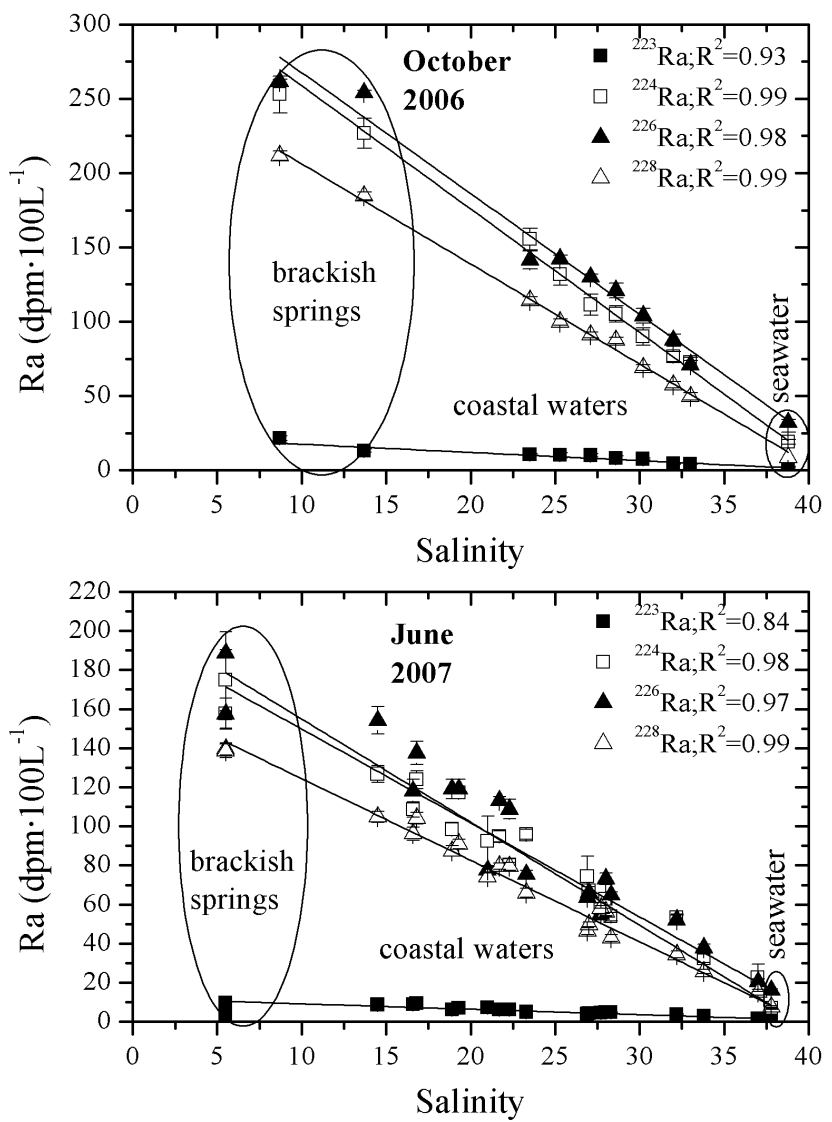

Fig. 5. Ra versus salinity plots for surface coastal waters, seawater and brackish spring groundwater samples indicating a mixing pattern of two end-members: seawater and groundwater.

\section{Discussion}

Submarine groundwater discharge forming a thin and fresher plume in the Badum coastal area was recognized by chemical tracer enrichments ( $\mathrm{Ra}$ isotopes and DSi) and lower salinity and temperature at all coastal stations relative to the open sea. In areas with well-defined seepage faces, SGD has been reported to behave following an exponential decrease offshore (Bokuniewicz et al., 2004; Lee, 1977). However, this conventional function, in the form SGD $=A \cdot e^{-c x}$ (where $A$ and $c$ are constants, and $x$ is the distance offshore; Bokuniewicz et al., 2004), does not govern the SGD flow in karstic areas, primarily due to the heterogeneity in boundary conditions at the shoreline. Fissuration and karstification processes at the Badum coastline (inset Fig. 1) lead to channelized discharge through brackish springs. Since it is an open site, the shape of the SGD plume at short time scales can be easily modified due to the prevailing currents and winds. As shown above (Fig. 5), a significant correlation between radium concentrations and salinity was obtained in coastal plume waters, i.e., radium activities were enriched in the fresher SGD plume compared to out of plume waters.
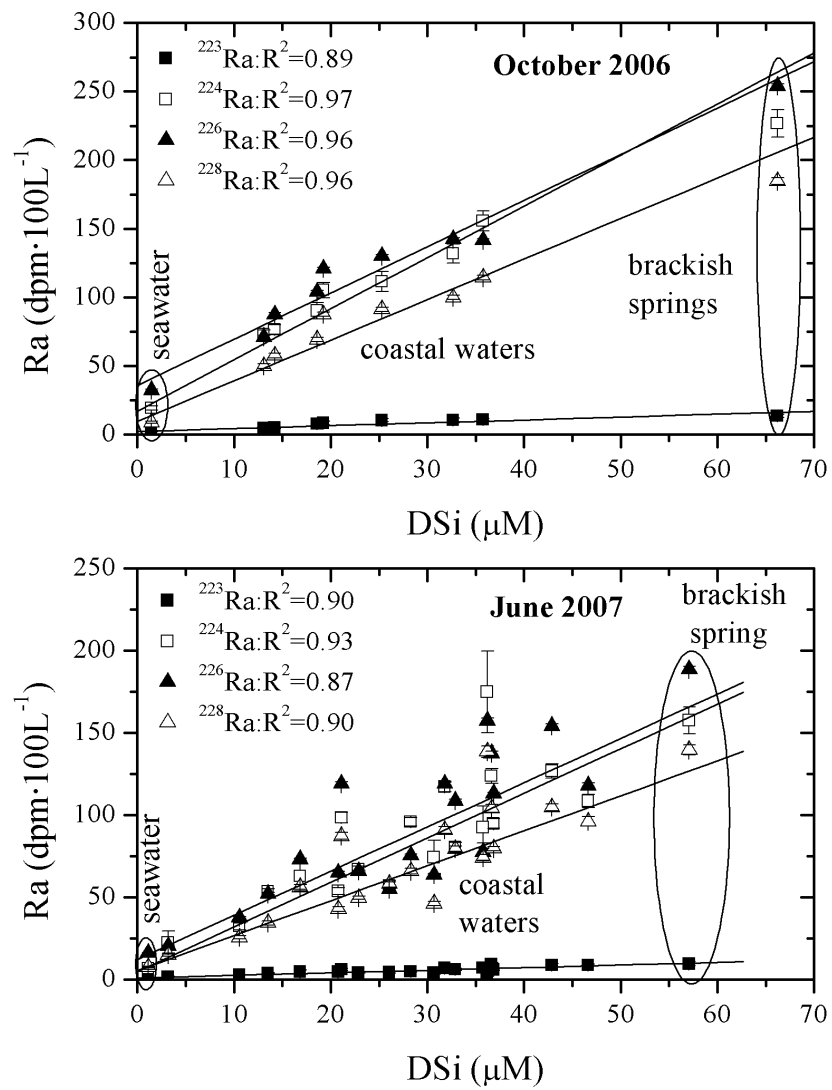

Fig. 6. Radium activities plotted against dissolved inorganic silica (DSi). Positive linear correlations are observed for all isotopes in October 2006 and June 2007, pointing to a conservative behavior of DSi once released from coastal brackish springs.

The estimation of SGD using the radium quartet requires identifying the possible sources of $\mathrm{Ra}$ in the coastal area. The significant linear correlations among radium isotopes in coastal plume waters, seawater and coastal brackish springs (Fig. 4) suggested that the two main endmembers that explain radium activities in the coastal area are seawater and brackish springs. Thereby, any other potential input of Ra (from sediments or possible deep springs) in surface coastal waters is negligible. Since dissolved inorganic silica and several major elements also showed significant linear correlations with all radium isotopes, it can be inferred that they experienced a similar conservative binary mixing pattern. While the distribution of DSi was found to be like that of radium (dilution from the enriched brackish springs to offshore; Fig. 6), major elements $(\mathrm{Cl}, \mathrm{S}, \mathrm{Ca}, \mathrm{K}, \mathrm{Br}$ and $\mathrm{Sr}$ ) showed the inverse relation, i.e., seawater is diluted by mixing with brackish groundwater. In addition, the low radium activities measured in water samples below the fresher layer confirm that the only input of $\mathrm{Ra}$ is the terrestrial source of brackish water via coastal springs. 
The SGD flux $\left(\mathrm{m}^{3} \mathrm{~d}^{-1}\right)$ to the Badum area can be estimated as described in Eq. (1):

$\mathrm{SGD}=\frac{f_{\mathrm{gw}} \cdot V}{T_{\mathrm{r}}}$

where $f_{\mathrm{gw}}$ is the groundwater fraction in coastal waters, $V$ is the volume affected by SGD $\left(\mathrm{m}^{3}\right)$ and $T_{\mathrm{r}}$ is the coastal waters residence time (days). These terms are established in the next sub-sections.

\subsection{Groundwater fraction $\left(f_{\mathrm{gw}}\right)$}

A simple two-endmember mixing model can be built, as described by Eq. (2, 3 and 4).

$f_{\mathrm{sw}}+f_{\mathrm{gw}}=1$

$f_{\mathrm{sw}} \cdot{ }^{226} \mathrm{Ra}_{\mathrm{sw}}+f_{\mathrm{gw}} \cdot{ }^{226} \mathrm{Ra}_{\mathrm{gw}}={ }^{226} \mathrm{Ra}_{\mathrm{cw}}$

$f_{\mathrm{sw}} \cdot{ }^{228} \mathrm{Ra}_{\mathrm{sw}}+f_{\mathrm{gw}} \cdot{ }^{228} \mathrm{Ra}_{\mathrm{gw}}={ }^{228} \mathrm{Ra}_{\mathrm{cw}}$

where $f_{\mathrm{sw}}$ is the seawater fraction in coastal waters, and ${ }^{226,228} \mathrm{Ra}_{\mathrm{sw}},{ }^{226,228} \mathrm{Ra}_{\text {spring }}$ and ${ }^{226,228} \mathrm{Ra}_{\mathrm{cw}}$ are the average activities in seawater, spring groundwater and coastal waters of Badum respectively. In this model, we assume that average radium activities in coastal waters are representative of the total area of the fresher plume. We have checked that by comparing radium averages of the total set of samples with radium averages of the stations in the central transect for the June 2007 sampling. Differences are of the order of 1 to $9 \%$, hence we estimate taking average activities is a good approximation.

In this study, we use groundwater radium activities measured concurrently with the coastal samplings, i.e., when the SGD fluxes are specifically determined (October 2006 and June 2007). Given the short water residence times (see SEct. 5.3) typical of open karstic coastal regions, this option is the most appropriate approach instead of using a temporally averaged endmember over several months. However, this latter method is conventionally applied in many SGD studies, and thus we have also calculated the groundwater fractions by applying the long-lived radium averages of the monthly groundwater samples set to compare with our approach.

Because of the conservative behavior of DSi and major elements, the same equations may be applied using these compounds instead of radium isotopes to estimate the groundwater fraction. The results obtained from the combination of two equations, always imposing that the sum of seawater and SGD fractions must be 1 (Eq. 2), are summarized in Table 3. Radium based groundwater fractions obtained from an overall spring's average are comparable to the groundwater fractions derived from our approach (groundwater endmember for each studied period) for the October sampling (difference of $3-5 \%$ ) but they are $\sim 30 \%$ lower for the June sampling
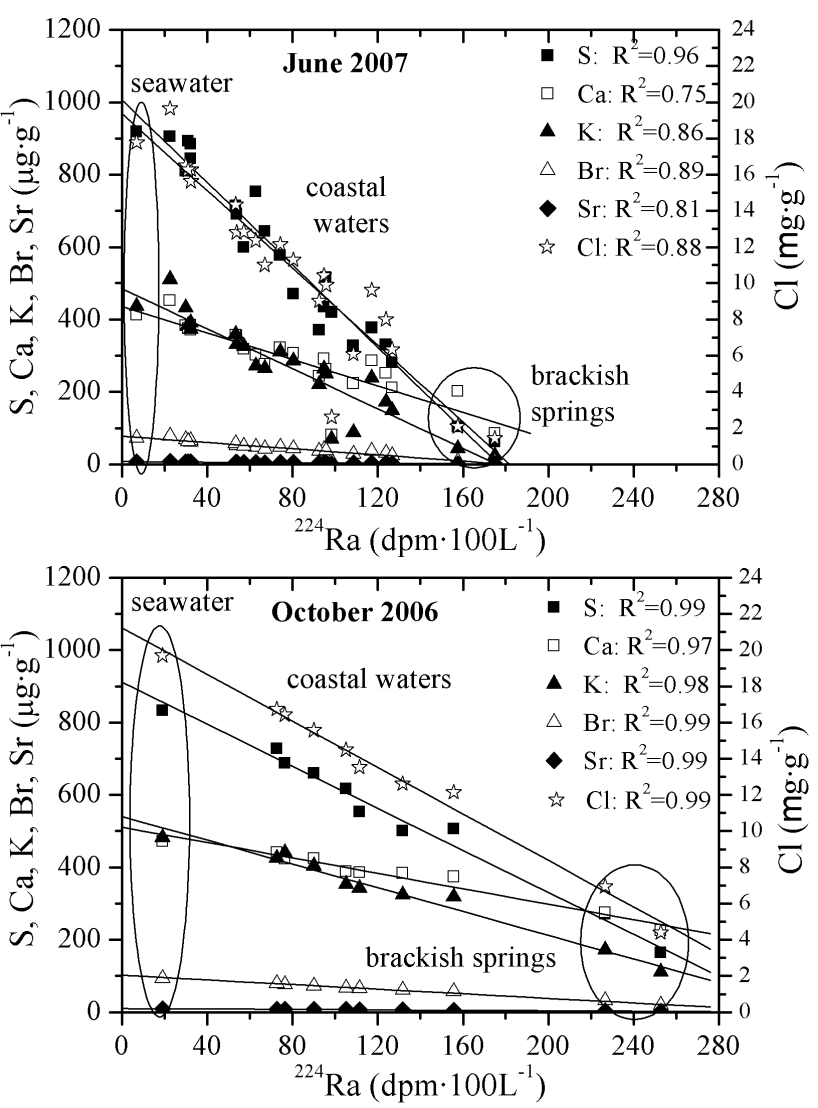

Fig. 7. Major element composition versus ${ }^{224} \mathrm{Ra}$ activities for October 2006 and June 2007.

(Table 3). This conventional approach would mask any temporal variability on the SGD fluxes, which constitutes one of the aims of the study, particularly in karstic environments.

Examining the group of tracers, all the estimates of seawater and groundwater fractions are in close agreement, with an average of $0.36 \pm 0.03$ for October 2006 and $0.44 \pm 0.03$ for June 2007, evidencing that surface waters in June contained about 22\% more brackish groundwater than in October.

\subsection{Volume of water column influenced by SGD (V)}

The total volume under study was calculated by multiplying the thickness of the water column influenced by SGD $(\mathrm{H})$ by the fresher plume area (A). From water column profiles of salinity at depth, water stratification was evidenced showing significantly fresher salinities from the surface down to only $40 \mathrm{~cm}$ depth (Fig. 3). Therefore, we define the model for the first $40 \mathrm{~cm}$. As for the area of the plume, it was determined from the salinity gridding (kriging method) considering the area delimited by the salinity contour of 36 . Thereby, the area of the SGD plume was determined to be of $2.1 \mathrm{~km}^{2}$ in June 2007 and $1.3 \mathrm{~km}^{2}$ in October 2006 (Fig. 8). With these values, the calculated water volumes affected by SGD for October 2006 and June 2007 are $540000 \mathrm{~m}^{3}$ and $850000 \mathrm{~m}^{3}$, respectively, with an estimated uncertainty of $\sim 10 \%$. 
Table 2. Temperature, salinity, radium activities and nutrient concentrations for the monthly collected brackish springs (nm refers to "notmeasured samples").

\begin{tabular}{|c|c|c|c|c|c|c|c|c|c|}
\hline \multirow{2}{*}{$\begin{array}{l}\text { monthly } \\
\text { springs }\end{array}$} & \multirow{2}{*}{$\begin{array}{c}T \\
\left({ }^{\circ} \mathrm{C}\right)\end{array}$} & \multirow[t]{2}{*}{ Sal } & \multicolumn{4}{|c|}{ Ra activity (dpm $\left.100 \mathrm{~L}^{-1}\right)$} & \multicolumn{3}{|c|}{ Nutrient concentration $(\mu \mathrm{M})( \pm 0.01)$} \\
\hline & & & ${ }^{223} \mathrm{Ra}$ & ${ }^{224} \mathrm{Ra}$ & ${ }^{226} \mathrm{Ra}$ & ${ }^{228} \mathrm{Ra}$ & DIN & DIP & $\mathrm{DSi}$ \\
\hline \multicolumn{10}{|l|}{2007} \\
\hline March & 18.9 & 9.4 & $14.2 \pm 1.6$ & $284 \pm 22$ & $334 \pm 2$ & $248 \pm 4$ & 69.4 & 0.16 & 47.7 \\
\hline April & 17.5 & 6.9 & $12.3 \pm 1.4$ & $233 \pm 18$ & $268 \pm 4$ & $183 \pm 7$ & 55.3 & 0.37 & 41.1 \\
\hline May & 18.1 & 5.0 & $10.1 \pm 1.3$ & $177 \pm 12$ & $\mathrm{~nm}$ & $\mathrm{~nm}$ & 52.5 & 0.44 & 44.5 \\
\hline June & 18.2 & 5.5 & $9.6 \pm 1.3$ & $158 \pm 8$ & $189 \pm 2$ & $140 \pm 3$ & 74.7 & 0.38 & 36.2 \\
\hline July & 18.2 & 5.6 & $9.1 \pm 1.3$ & $164 \pm 9$ & $206 \pm 8$ & $155 \pm 10$ & 72.1 & 0.34 & 44.3 \\
\hline August & 18.3 & 6.4 & $12.7 \pm 1.5$ & $217 \pm 14$ & $258 \pm 12$ & $219 \pm 8$ & 58.9 & 0.68 & 90.3 \\
\hline October & 19.1 & 8.4 & $11.7 \pm 1.0$ & $261 \pm 15$ & $318 \pm 6$ & $227 \pm 4$ & 87.2 & 0.28 & 39.3 \\
\hline November & 18.9 & 8.0 & $11.4 \pm 1.1$ & $265 \pm 24$ & $\mathrm{~nm}$ & $\mathrm{~nm}$ & 59.1 & 0.28 & 48.0 \\
\hline December & 18.7 & 8.8 & $14.4 \pm 1.6$ & $263 \pm 14$ & $282 \pm 7$ & $236 \pm 10$ & 100.5 & 0.54 & 63.2 \\
\hline \multicolumn{10}{|l|}{2008} \\
\hline January & 17.7 & 5.2 & $9.4 \pm 0.8$ & $183 \pm 9$ & $189 \pm 7$ & $174 \pm 6$ & 97.6 & 0.45 & 77.2 \\
\hline February & 18.1 & 5.5 & $9.2 \pm 0.8$ & $195 \pm 9$ & $176 \pm 5$ & $148 \pm 4$ & 59.6 & 0.49 & 70.8 \\
\hline
\end{tabular}

\subsection{Coastal waters residence time $\left(T_{\mathbf{r}}\right)$}

Ratios between short-lived and longer-lived radium isotopes can be used to calculate water apparent ages in coastal regions (Moore, 2000). Depending on the expected water residence time and the potential radium endmembers in the studied coastal area, one can choose ${ }^{224} \mathrm{Ra}$ or ${ }^{223} \mathrm{Ra}$ as a shortlived isotope and ${ }^{223} \mathrm{Ra},{ }^{226} \mathrm{Ra}$ or ${ }^{228} \mathrm{Ra}$ as the long-lived. Considering that the studied karstic system is an open coastal area, a very short coastal water residence time is expected so that we will use ${ }^{224} \mathrm{Ra}$ as the sort-lived radium isotope. On the other hand, seawater (which mixes with fresher plume waters) carries a significant load of the long-lived ${ }^{226} \mathrm{Ra}$ and ${ }^{228} \mathrm{Ra}$ isotopes (e.g., from SGD and/or riverine discharge occurring in surrounding areas), precluding the use of the ${ }^{224} \mathrm{Ra} /{ }^{228} \mathrm{Ra}$ AR method to estimate water apparent ages.

Therefore, the use of ${ }^{223} \mathrm{Ra}$ and ${ }^{224} \mathrm{Ra}$ isotopes as a method to estimate water apparent ages of the SGD is the most appropriate in our karstic setting. It is noted here that it is not easy to appreciate the decay of the shortest-lived ${ }^{224} \mathrm{Ra}$ within the sampled coastal plume waters, likely masked by statistical uncertainties. Considering the analytical errors associated with the measurement of ${ }^{223} \mathrm{Ra}$ and ${ }^{224} \mathrm{Ra}$, the ${ }^{223} \mathrm{Ra} /{ }^{224} \mathrm{Ra}$ ratios in the water plume fall within the error range of the original (groundwater) ratio for a certain period of time. This time depends on the relative errors associated with ${ }^{223} \mathrm{Ra}$ and ${ }^{224} \mathrm{Ra}$ and the decay constants of these Ra isotopes and can be calculated according to Knee et al. (2010). In our study, the average relative errors of the groundwater endmember (considering all monthly collected samples) are $8 \%$ for ${ }^{224} \mathrm{Ra}$ and $11 \%$ for ${ }^{223} \mathrm{Ra}$ so that the minimum residence time that may be calculated via the ${ }^{224} \mathrm{Ra} /{ }^{223} \mathrm{Ra}$ ratio is of $27 \mathrm{~h}$ (1.1 days).
Table 3. Coastal plume water fractions of brackish groundwater $\left(f_{\mathrm{gw}}\right)$ and seawater $\left(f_{\mathrm{cs}}\right)$ derived from the mixing models with the set of tracers. Groundwater fractions shown in brackets are calculated assuming the same groundwater radium average for the two samplings (see text for details).

\begin{tabular}{ccccc}
\hline \multirow{2}{*}{ Equations } & \multicolumn{2}{c}{ October 2006} & \multicolumn{2}{c}{ June 2007} \\
& $f_{\mathrm{gw}}$ & $f_{\mathrm{cs}}$ & $f_{\mathrm{gw}}$ & $f_{\mathrm{cs}}$ \\
\hline${ }^{226} \mathrm{Ra}$ & $0.36(0.38)$ & 0.64 & $0.44(0.30)$ & 0.56 \\
${ }^{228} \mathrm{Ra}$ & $0.38(0.39)$ & 0.62 & $0.44(0.31)$ & 0.56 \\
$\mathrm{DSi}$ & 0.33 & 0.67 & 0.51 & 0.49 \\
$\mathrm{Cl}$ & 0.37 & 0.63 & 0.41 & 0.59 \\
$\mathrm{~S}$ & 0.37 & 0.63 & 0.42 & 0.58 \\
$\mathrm{Ca}$ & 0.31 & 0.69 & 0.44 & 0.56 \\
$\mathrm{~K}$ & 0.32 & 0.68 & 0.41 & 0.59 \\
$\mathrm{Br}$ & 0.36 & 0.64 & 0.43 & 0.57 \\
$\mathrm{Sr}$ & 0.39 & 0.61 & 0.43 & 0.57 \\
$f_{\mathrm{gw}}$ average & $0.36 \pm 0.03$ & & $0.44 \pm 0.03$ & \\
\hline
\end{tabular}

Figure 9 depicts ${ }^{224}$ Ra vs. ${ }^{223} \mathrm{Ra}$ activities for surface water samples in both samplings and the coastal spring endmembers. In order to minimize the potential bias caused by any heterogeneous spatial sampling, we here use slopes rather than activity ratio averages. Notice that this approach cannot be used in the mixing model to calculate endmember fractions, since they are already implicitly included in the activity ratio terms. Best-fit lines produce a ${ }^{224} \mathrm{Ra} /{ }^{223} \mathrm{Ra}$ activity ratio for springs $\left(\mathrm{AR}_{\mathrm{gw}}\right)$ of $18.5 \pm 0.3$. For coastal waters, the derived activity ratios $\left(\mathrm{AR}_{\mathrm{cw}}\right)$ would be $13.1 \pm 0.2$ (October 2006) and 14.2 \pm 0.1 (June 2007). We then can use 


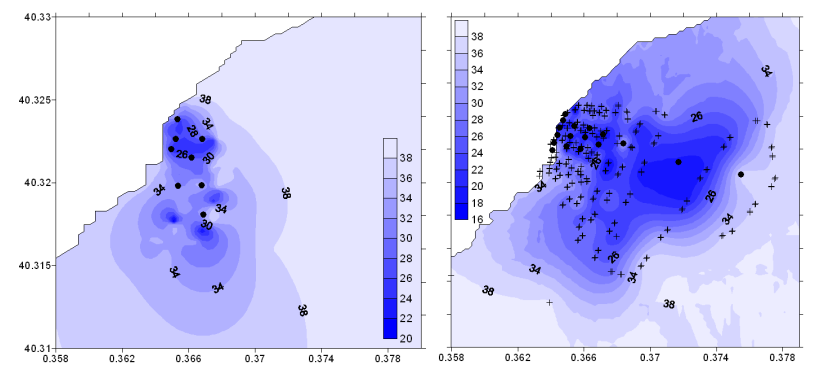

Fig. 8. Salinity contour plots for Badum surface coastal waters in October 2006 (left side) and June 2007 (right side).

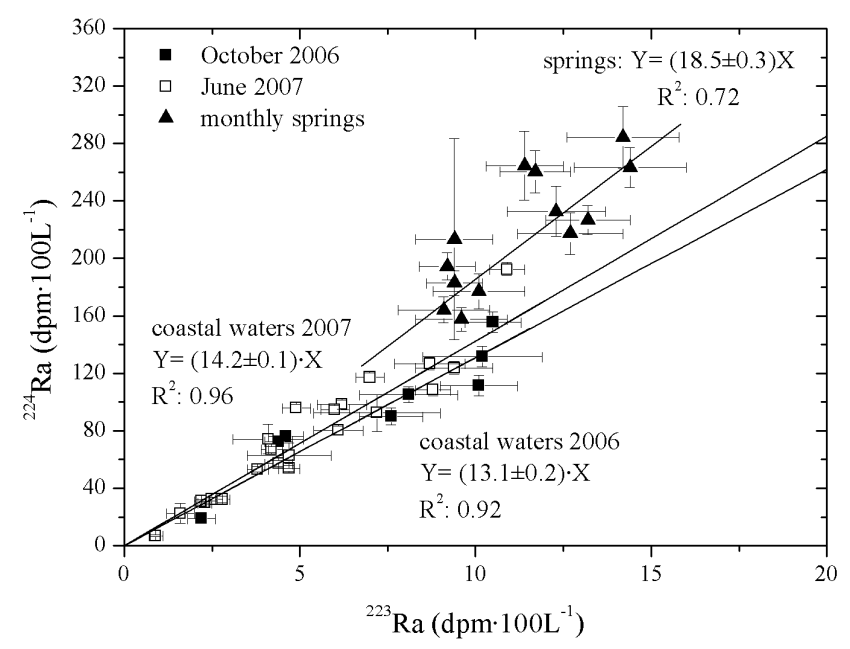

Fig. 9. ${ }^{224} \mathrm{Ra}$ activities plotted versus ${ }^{223} \mathrm{Ra}$ in surface waters from October 2006 and June 2007 and the monthly collected brackish springs. The best-fit lines for the three cases are also specified.

the difference between $\mathrm{AR}_{\mathrm{gw}}$ and $\mathrm{AR}_{\mathrm{cw}}$ to estimate a maximum water apparent age or residence time of plume waters (Moore, 2000; Moore, 2006a):

$T_{\mathrm{r}}(d)=\frac{\operatorname{Ln}\left(\frac{\mathrm{AR}_{\mathrm{gw}}}{\mathrm{AR}_{\mathrm{cw}}}\right)}{0.129}$

Equation (5) takes into account the more rapid decay of ${ }^{224} \mathrm{Ra}$ relative to ${ }^{223} \mathrm{Ra}$, with the $0.129 \mathrm{~d}^{-1}$ value accounting for the difference in the ${ }^{224} \mathrm{Ra}$ and ${ }^{223} \mathrm{Ra}$ decay constants. Applying Eq. (5), an upper limit residence time of $2.7 \pm 0.2$ days for water sampled in October is obtained, which is slightly higher than the estimated maximum water residence time in June, of $2.0 \pm 0.1$ days. These estimates are well above the minimum residence time that can be calculated using our data, as detailed above. Therefore, we can use the ${ }^{224} \mathrm{Ra} /{ }^{223} \mathrm{Ra}$ ratio to calculate the upper limit estimates for the water residence time, and thus leading to conservative, minima estimations of the SGD fluxes.

\subsection{Determination of the SGD fluxes}

Once all the necessary terms have been estimated, conservative SGD fluxes were derived from Eq. (1), resulting in $71500 \pm 11200 \mathrm{~m}^{3} \mathrm{~d}^{-1}$ in October 2006 and $187000 \pm$ $23000 \mathrm{~m}^{3} \mathrm{~d}^{-1}$ in June 2007. Given the salinities of the coastal springs in October 2006 (average of 11,2) and June (average of 5,5), the fresh SGD portion can be estimated for both periods: $50500 \mathrm{~m}^{3} \mathrm{~d}^{-1}$ in October 06 and $159400 \mathrm{~m}^{3} \mathrm{~d}^{-1}$ in June 07 . These fluxes for the Badum site would account for $30 \%$ to $90 \%$ of the hydrologically estimated SGD flux for the three main coastal areas of the Irta Mountains, i.e., Badum, Peníscola and Alcossebre ( $\sim 175000 \mathrm{~m}^{3} \mathrm{~d}^{-1}$; Serrano et al., 1995).

Other works on SGD in Mediterranean costal regions have been carried out during the last few years, obtaining a wide range of SGD fluxes estimates. Swarzenski et al. (2006) used ${ }^{222} \mathrm{Rn}$ to quantify SGD fluxes in Israel (Dor Beach) of $7100 \mathrm{~m}^{3} \mathrm{~d}^{-1}$ per $\mathrm{km}$ of shoreline, which are two orders of magnitude lower than our coastline normalized SGD fluxes of 120000 and $311000 \mathrm{~m}^{3} \mathrm{~d}^{-1} \mathrm{~km}^{-1}$. Even higher is the difference with Ra-based SGD fluxes in a Minorca cove (Balearic Islands), assessed in $660 \mathrm{~m}^{3} \mathrm{~d}^{-1} \mathrm{~km}^{-1}$ by GarciaSolsona et al. (2010). On the other hand, Moore (2006a) estimated comparable groundwater flows (of $10^{6} \mathrm{~m}^{3} \mathrm{~d}^{-1} \mathrm{~km}^{-1}$ ) in the southern coast of Sicily (Donnalucata). Peterson et al. (2009) examined SGD fluxes forming buoyant fresher layers from point-source discharges along the western coast of the Big Island of Hawaii. They estimated total SGD fluxes ranging from 1100 to $12000 \mathrm{~m}^{3} \mathrm{~d}^{-1}$. In contrast with our study, Peterson et al. (2009) could not use radium isotopes to derive the SGD fluxes because they did not find Ra enrichment in groundwater, probably due to excessively fresh groundwater samples or a too narrow subterranean estuary band. Instead of radium, they applied ${ }^{222} \mathrm{Rn}$ to assess SGD fluxes and overcome the difficulty of estimating short (hours to days) water residence times by performing time-series radon measurements.

Estimates of submarine groundwater discharge fluxes are always subject to inherent uncertainties associated with sampling and analytical measurements. In our model, the final uncertainty associated with the SGD flux depends on the groundwater fraction, the estimated fresher plume volume and the water residence time in the studied area. The variation of each of these terms implies a linear change in the estimated SGD flux. In our study, the groundwater endmember is presumably affected by a low uncertainty, since all the independent tracers to estimate it give consistent values, as shown by the small standard deviation of the calculated fractions. As for the coastal volume under study, we are confident that the area of the plume has been well delimited by means of the salinity gridding but we are also aware that its shape may be variable at relatively short time scales, implying a higher uncertainty propagated to the SGD flux. Finally, our water residence times are likely subject to 
Table 4. Accumulated precipitation during the previous months before sampling in October 2006 and June 2007 and ratios between samplings.

\begin{tabular}{lccccc}
\hline & \multicolumn{5}{c}{ Accumulated precipitation in previous to sampling months $\left(\mathrm{L} \mathrm{m}^{-2}\right)$} \\
& 2 months & 3 months & 4 months & 5 months & 6 months \\
\hline October 2006 & 79 & 92 & 108 & 144 & 157 \\
June 2007 & 238 & 300 & 320 & 361 & 368 \\
$2007 / 2006$ ratio & 3.0 & 3.2 & 3.0 & 2.5 & 2.3 \\
\hline
\end{tabular}

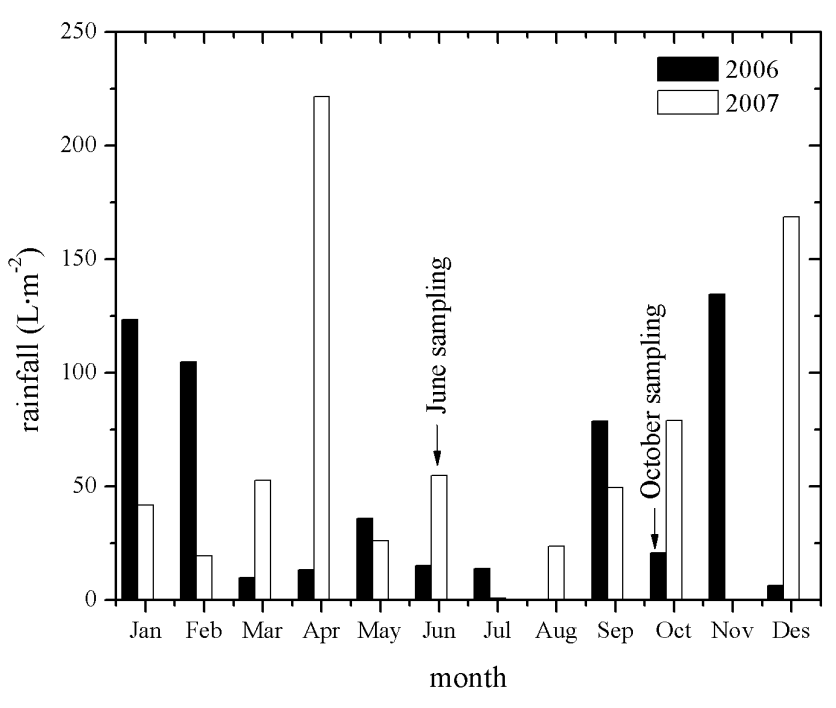

Fig. 10. Monthly precipitation in the Badum area during 2006 and 2007. The dates of the sampling campaigns are indicated. The highest precipitation peak was observed in April 2007, while September 2006 also represented, to a lesser extent, a wet month.

higher uncertainties due to the difficulty in assessing them in coastal areas affected by a extremely rapid mixing from hours-to-few days. We have essentially estimated maxima water residence times, which result in conservative estimates of the SGD fluxes. Implementing the minimum water residence time than can be determined following Moore (2000) equation for our setting (1.1 days; Knee et al., 2010), the estimated maxima SGD fluxes would be 2.5 and 1.8 times higher for October 2006 and June 2007 samplings, respectively.

\subsection{Variability in SGD estimates}

Changes in rainfall constitute an important element responsible for seasonal variability observed in SGD, as recharge rates directly affect hydraulically-driven groundwater flow. In addition, the seasonality in precipitation will also influence the recirculated part of SGD, since migrations of the saltwater/freshwater interface with time are controlled by seasonal changes in water table elevation (Michael et al., 2005).
Data on precipitation in the Maestrat Aquifer region was obtained from the pluviometric stations of the Spanish Meteorological Agency (AEMET) at Alcala de Chivert $\left(40^{\circ} 17^{\prime} \mathrm{N} ; 0^{\circ} 15^{\prime} \mathrm{E}, 200 \mathrm{~m}\right.$ a.s.1.) and Vilafranca del Cid $\left(40^{\circ} 26^{\prime} \mathrm{N} ; 0^{\circ} 15^{\prime} \mathrm{W}, 1130 \mathrm{~m}\right.$ a.s.l.). Considering a 40 years period (1965/66-2007/08), the average precipitation was $518 \mathrm{~L} \mathrm{~m}^{-2}$, with important differences in precipitation between wet and dry years (a minimum of $315 \mathrm{~L} \mathrm{~m}^{-2}$ was recorded in 1993/94 and a maximum of $1003 \mathrm{~L} \mathrm{~m}^{-2}$ in 1971/72). More precisely, 2006 was an intermediate year $\left(568 \mathrm{~L} \mathrm{~m}^{-2}\right)$ while 2007 was a relatively wet year $\left(725 \mathrm{~L} \mathrm{~m}^{-2}\right)$. The monthly distribution of rainfall for 2006 and 2007 is shown in Fig. 10. Unlike June 2007, the October 2006 sampling was immediately preceded by a rainy month (Fig. 10). However, the fresh-SGD flux estimated in October 2006 was only a $32 \%$ of the flux calculated for the June 2007 period, revealing that SGD fluxes may not respond rapidly to precipitation. Conversely, the higher SGD estimate in June 2007 likely reflects the strong precipitation occurred in April of the same year (Fig. 10). By calculating the accumulated precipitation during several months previous to sampling, we obtained that the 2007/2006 precipitation ratio (3.2) agrees with the 2007/2006 fresh-SGD ratio (3.2) when integrating three months (Table 4). This suggests that the estimated fresh-SGD fluxes respond the actual amount of freshwater infiltrated in the precedent $\sim 3$ months. This lag of approximately three months is somewhat shorter than the accounted values from other studies in non-karstic aquifers, which determined up to semi-annual lag effects when directly comparing SGD fluxes with precipitation maxima (Michael et al., 2005; Smith et al., 2008).

Regarding the SGD endmember temporal variability, we observed that coastal springs generally presented higher salinities in autumn than in summer months (Table 2). This points to a general weaker proportion of fresh SGD in autumn months due to a lower water table pressure (in response to dry summers), in addition to a smaller total SGD flux. Indeed, spring's groundwater salinities were positive linearly correlated with radium activities $\left(R^{2}=0.83\right.$, $p<0.0001$ for ${ }^{224} \mathrm{Ra} ; R^{2}=0.63, p=0.002$ for ${ }^{223} \mathrm{Ra}$; $R^{2}=0.97, p<0.0001$ for ${ }^{226} \mathrm{Ra}$ and $R^{2}=0.89, p<0.0001$ for ${ }^{228} \mathrm{Ra}$, figures not shown). These results evidence that higher 

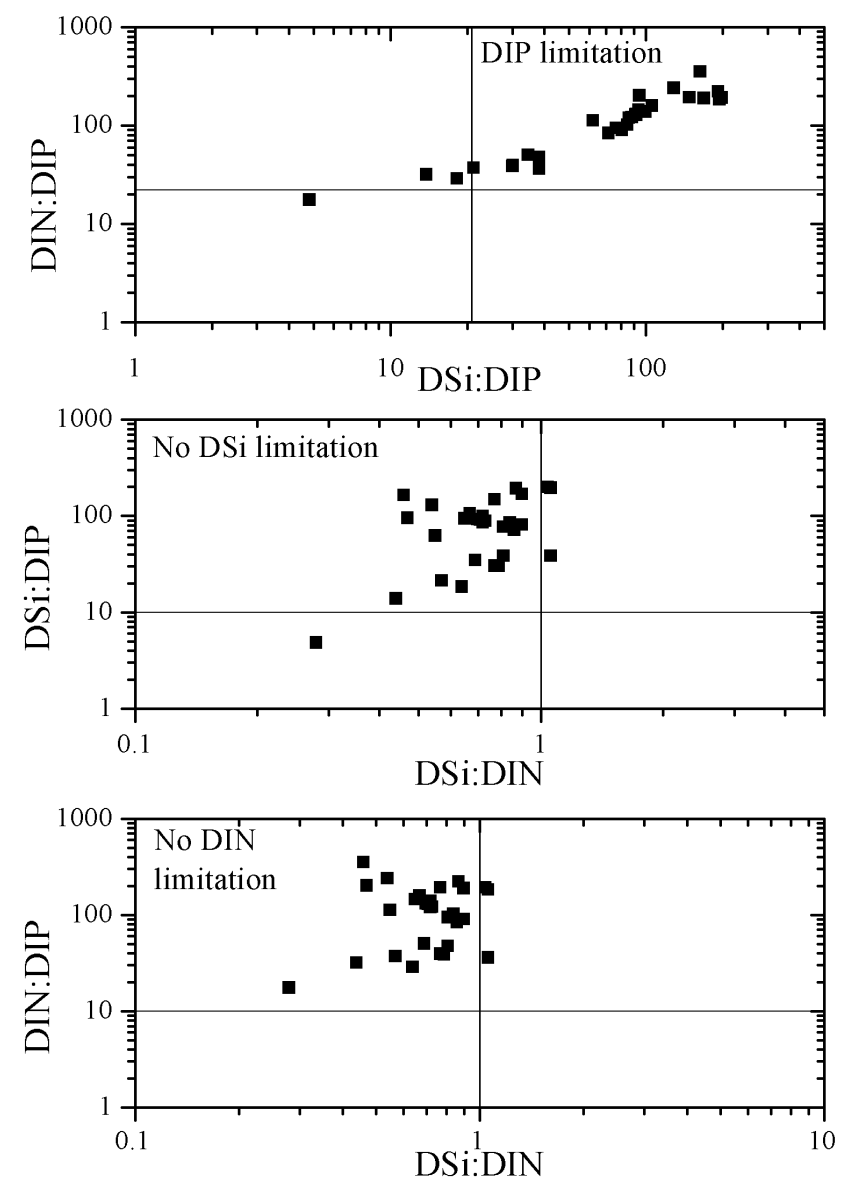

Fig. 11. Nutrient ratios diagrams for Badum coastal water samples suggesting phosphorus limitation.

radium activities in groundwater occurred when lower SGD rates were estimated, which actually allowed a higher radium enrichment in the springs.

\subsection{Nutrient inputs via SGD}

The fluxes of dissolved inorganic nutrients can be calculated by multiplying the SGD flux by the concentration of nutrients in the groundwater endmember. This method can be applied when (i) nutrients behave conservatively along its path from the groundwater sampling station to the discharging point, or (ii) groundwater nutrient concentration is sampled right at the discharging location, like in our case. Then, the resulting SGD-associated nutrient flows were 1500 and $8300 \mu \mathrm{mol} \mathrm{m}^{-2} \mathrm{~d}^{-1}$ of DIN and 19 and $40 \mu \mathrm{mol} \mathrm{m}^{-2} \mathrm{~d}^{-1}$ of DIP in the October 2006 and June 2007, respectively. Since the sampled springs are not completely fresh (average salinities of 5.5 and 11.2 for June 07 and October 2006), these fluxes may include both new and recirculated nutrients. Although expected to be low, a certain load of recirculated nutrients may enter the fractured coastal aquifer with the portion of intruding seawater and mix with new nutrients before flowing back to the coastal sea through the springs.
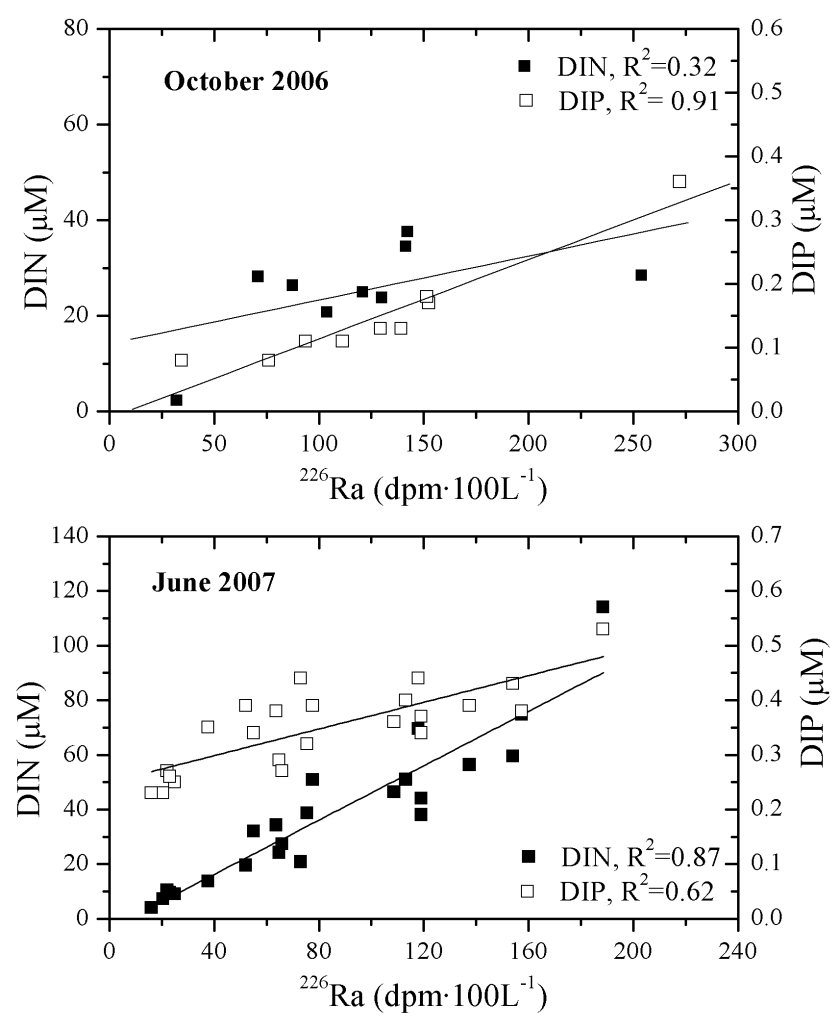

Fig. 12. DIN (solid squares) and DIP (open squares) versus ${ }^{226} \mathrm{Ra}$ for coastal waters in October 2006 and June 2007 surveys.

Given that basically rural areas without significant presence of intense farming and cattle activities surround Badum, no large anthropogenic pollutant load is expected in groundwater. Therefore, the estimated inputs of nutrients are presumably of mainly natural origin. Our calculated rates of DIP fit within the low part of the reported range in different regions (9-900 $\mu \mathrm{M} \mathrm{m}^{-2} \mathrm{~d}^{-1}$; Slomp and Van Cappellen, 2004), while the estimated DIN fluxes are consistent with the upper limit or even higher than other accounted natural inputs (160-2400 $\mu \mathrm{M} \mathrm{m}^{-2} \mathrm{~d}^{-1}$; Slomp and Van Cappellen, 2004).

DIN concentrations showed significant correlation with radium activities (e.g., with ${ }^{226} \mathrm{Ra}: R^{2}=0.87$, Fig. 12) and salinity $\left(R^{2}=0.88\right)$ in the summer period, in contrast with the situation in autumn $\left({ }^{226} \mathrm{Ra}: R^{2}=0.32\right.$, Fig. 12 ; salinity: $R^{2}=0.30$ ). The contrary trend is observed for DIP measurements, with a significant correlation with $\mathrm{Ra}\left({ }^{226} \mathrm{Ra}\right.$ : $\left.R^{2}=0.91\right)$ and salinity $\left(R^{2}=0.88\right)$ in autumn and a notably lower relationship in summer (with ${ }^{226} \mathrm{Ra}: R^{2}=0.62$, Fig. 12; salinity: $R^{2}=0.45$ ). This may suggest that physical mixing of SGD with seawater, rather than biological uptake or chemical reactions, is the prevailing process determining the nitrogen distribution in coastal waters in the summer survey. This is also in accordance with the shorter coastal water residence time in summer. The lower SGD flow estimated in autumn may allow incomplete denitrification reactions in coastal waters, given that the proportion of $\mathrm{NO}_{2}$ (produced as intermediate compound) to $\mathrm{NO}_{3}$ is higher (Uchiyama et 
al., 2000). The inverse behavior of DIP probably indicates that its concentrations in surface waters in the autumn period are entirely explained by seawater-groundwater mixing. In the summer time, phosphorus data are more scattered, potentially implying active biological uptake by phytoplankton communities in coastal waters, a process that is indeed activated by higher temperatures in that season. However, detailed investigations should be conducted to determine which mechanisms are actually responsible of the dissolved inorganic nutrient distributions in coastal waters.

According to the Redfield ratio ( $\mathrm{Si}: \mathrm{N}: \mathrm{P}=16: 16: 1)$, the stoichiometric limitation criteria set by Justic et al. (1995) suggest that the Badum coastal waters would be limited by phosphorus ( $\mathrm{Si}: \mathrm{N}: \mathrm{P}=16: 12: 0.2$; Fig. 11), similarly to other coastal areas in the NW Mediterranean region (Diaz et al., 2001). In karstic areas, $P$ limitation may be driven by sequestration of $\mathrm{P}$ in calcareous sediments (Elser et al., 2007). Phosphorus has been reported as potentially having greater regulatory importance than nitrogen in several coastal areas (Bonin et al., 1989; Heiskanen et al., 1996; Mahoney, 1989). The estimated SGD associated fluxes of nutrients could indeed alter the nutrient equilibrium of the Badum biological community since coastal stations barely influenced by SGD (A7 in October 2006 and S16 in June 2007) presented Si:N:P ratios with higher $\mathrm{N}$ and $\mathrm{P}$ with respect to $\mathrm{Si}$ (i.e., 16:25:0.9 and 16:58:3.3, respectively) than all the other stations inside the fresher SGD plume (average of 16:22:0.1 in October and 16:23:0.3 in June). The latter are in turn more similar to those nutrient ratios in spring groundwater (16:7:0.09 in October and 16:31:0.16 in June). In addition, the N:P ratios out of the plume coastal waters (average of 16:0.6 in October and 16:0.9 in June) were closer to Redfield than coastal plume waters affected by SGD (average of 16:0.07 in October and 16:0.2 in June), which actually pointed to $\mathrm{P}$ limitation.

\section{Conclusions}

Radium isotopes have been used, together with DSi and major elements distributions, to investigate SGD through karstic springs into the coastal area of Badum (Castello, Spain) in two different periods: October 2006 and June 2007. Salinity profiles evidenced a strong density gradient with a fresher surface layer of $40 \mathrm{~cm}$ produced by SGD. This fresher plume was recorded by thermal infrared images in June 2006, and resulted to be similar in size than the plume estimated from salinity measurements in June $2007\left(2.1 \mathrm{~km}^{2}\right)$, while the area influenced by SGD was of about $1.3 \mathrm{~km}^{2}$ in October 2006. Short-lived radium isotopes have been used to estimate maxima water apparent ages for the study site, resulting in 2.7 days in October and 2.0 days in June. By applying a mass balance model for radium, DSi and major elements in the coastal area, the brackish groundwater fraction of the plume waters averaged $36 \pm 3 \%$ in October 2006 and $44 \pm 3 \%$ in June 2007. These estimates allowed us to calculate a conservative total SGD flux of $71400 \mathrm{~m}^{3} \mathrm{~d}^{-1}$ in October 2006 and $186500 \mathrm{~m}^{3} \mathrm{~d}^{-1}$ in June 2007, the respective fresh-SGD proportions being $71 \%$ and $85 \%$. The higher SGD rate calculated in summer is in agreement with the elevated precipitation occurred in the preceding months. Indeed, SGD can be related to the precipitation occurred during the three months preceding each sampling. This lag between coastal groundwater discharge and precipitation events suggest that the mean residence times of fresh groundwater in the aquifer would be of the same order. The SGD fluxes are also used to estimate the associated input of DIN and DIP to the coastal area, which turned out to be around 1500 and $8300 \mathrm{mM} \mathrm{m}^{-2} \mathrm{~d}^{-1}$ of DIN and 19 and $40 \mathrm{mM} \mathrm{m}^{-2} \mathrm{~d}^{-1}$ of DIP in the autumn and summer periods, respectively. These, presumably natural, inputs of nutrients are delivered to the sea with a clear depletion of $\mathrm{P}$ (Si:N:P in brackish spring groundwater of 16:7:0.09 in October and 16:31:0.16 in June), which may induce or increase P limitation in the coastal waters and, therefore, alter the structure of biological communities in the region.

Acknowledgements. We want to specially acknowledge R. Ventosa (ICM) for her assistance with nutrient analyses and the Marine Environment Laboratory (IAEA, in Monaco) for the major element measurements. The authors gratefully thank our colleagues at the Laboratori de Radioactivitat Ambiental for their help and assistance during field work. This project has been funded by the Spanish Government project EDASMAR (CGL2006-09274/HID). Support from the Fulbright Commission for a post-doctoral fellowship to J.G-O. (ref 2007-0516) is gratefully acknowledged. Support for the research of PM was received through the prize ICREA Academia, funded by the Generalitat de Catalunya.

Edited by: M. Dai

\section{References}

Antón-Pacheco, C., Ballesteros, B. J., Mejías, M., de Miguel, E., Gumiel, J. C., Gómez, J. A., and Calleja, P.: Identificación y cartografía de surgencias costeras en el acuífero kárstico de El Maestrazgo (Castellón) mediante técnicas de teledetección aeroportada en el infrarrojo térmico (Identification and mapping of coastal outflows from the El Maestrazgo karstic aquifer (Castellón) using airborne detection systems in the thermal infrared), Boletín Geológico y Minero, 118, 2007, (in Spanish).

Bakalowicz, M., El-Hakim, M., and El-Hajj, A.: Karst groundwater resources in the countries of Eastern Mediterranean: the example of Lebanon, Environ. Geol., 54, 597-604, 2008.

Ballesteros, B. J.: Estudio Hidrogeológico del Maestrazgo, Castellón, Instituto Geológico y minero de España documentation center, 158 pp., 1989.

Basterretxea, G., Garcés, E., Jordi, A., Masó, M., and Tintoré, J.: Breeze conditions as a favoring mechanism of Alexandrium taylori blooms at a Mediterranean beach, Estuar. Coast. Shelf S., 62, 1-12, 2005.

Basterretxea, G., Tovar-Sanchez, A., Beck, A.J., Masqué, P., Bokuniewicz, H., Coffey, R., Duarte, C. M., Garcia-Orellana, J., 
Garcia-Solsona, E., Martinez-Ribes, L., and Vaquer-Sunyer, R.: Submarine groundwater discharge to the coastal environment of a Mediterranean island (Majorca, Spain): ecosystem and biogeochemical significance, Ecosystems, 13(5), 629-643, 2010.

Bear, J., Cheng, A., Sorek, S., Ouazar, D., and Herrera, I.: Seawater Intrusion in Coastal Aquifers - Concepts, Methods and Practices, Dordrecht, Kluwer Academic Publishers, 1999.

Boehm, A. B., Shellenbarger, G. G., and Paytan A.: Groundwater Discharge: potential Association with Fecal Indicator Bacteria in the Surf Zone, Environ. Sci. Technol., 38(13), 3558-3566, 2004.

Bokuniewicz, H., Pollock, M., Blum, J., and Wilson, R.: Submarine Ground Water Discharge and Salt Penetration Across the Sea Floor, Ground Water, 42(7), 983-989, 2004.

Bonin, D. J., Bonin, M. C., and Berman, T.: Experimental evidence of nutrients limiting the production of micro-nanoplankton and ultraplankton in the coastal waters of the eastern Mediterranean ocean, Haifa, Israel. Aquat. Sci., 51(2), 129-152, 1989.

Borum, J.: Shallow waters and land/sea boundaries, Coast. Estuar. Stud., 52, 1-19, 1996.

Burnett, W. C., Bokuniewicz, H., Huettel, M., Moore, W. S., and Taniguchi, M.: Groundwater and pore water inputs to the coastal zone, Biogeochemistry, 66, 3-33, 2003.

Burnett, W. C., Aggarwal, P. K., Bokuniewicz, H., Cable, J. E., Charette, M. A. Kontar, E., Krupa, S., Kulkarni, K. M., Loveless, A., Moore, W. S., Oberdorfer, J. A., Oliveira, J., Ozyurt, N., Povinec, P., Privitera, A. M. G., Rajar, R., Ramessur, R. T., Scholten, J., Stieglitz, T., Taniguchi, M., and Turner, J. V.: Quantifying Submarine Groundwater Discharge in the Coastal Zone via Multiple Methods, Sci. Total Environ., 367(2-3), 498-543, 2006.

Charette, M. A., Buesseler, K. O., and Andrews, J. E.: Utility of radium isotopes for evaluating the input and transport of groundwater-derived nitrogen to a Cape Cod estuary, Limnol. Oceanogr., 46, 465-470, 2001.

Cooper, H. H., Jr.: A hypothesis concerning the dynamic balance of freshwater and saltwater in a coastal aquifer, J. Geophys. Res., 64, 461-467, 1959.

Corbett, D. R., Dillon, K., Burnett, W., and Chanton, J.: Estimating the groundwater contribution into Florida Bay via natural tracers, ${ }^{222} \mathrm{Rn}$ and $\mathrm{CH}_{4}$, Limnol. Oceanogr., 45(7), 1546-1557, 2000.

Diaz, F., Raimbault, P., Boudjellal, B., Garcia, N., and Moutin, T.: Early spring phosphorus limitation of primary productivity in a NW Mediterranean coastal zone (Gulf of Lions), Mar. Ecol-Prog. Ser., 211, 51-62, 2001.

Elser, J. J., Bracken, M. E. S., Cleland, E. E., Gruner, D. S., Harpole, W. S., Hillebrand, H., Ngai, J. T., Seabloom, E. W., Shurin, J. B., and Smith, J. E.: Global analysis of nitrogen and phosphorus limitation of primary producers in freshwater, marine and terrestrial ecosystems, Ecol. Lett., 10, 1135-1142, 2007.

Garcés, E., Masó, M., and Camp, J.: A recurrent and localized dinoflagellate bloom in a Mediterranean beach, J. Plankton Res., 21(12), 2373-2391, 1999.

Garcia-Solsona, E., Garcia-Orellana, J., Masque, P., and Dulaiova, H.: Uncertainties associated with Ra-223 and Ra-224 measurements in water via a Delayed Coincidence Counter (RaDeCC), Mar. Chem., 109(3-4), 198-219, 2008.

Garcia-Solsona, E., Garcia-Orellana, J., Masqué, P., Garcés, E., Radakovitch, O., Mayer, A., Estradé, S., and Basterretxea, G.: An assessment of karstic submarine groundwater and associated nutrient discharge to a Mediterranean coastal area (Balearic Islands, Spain) using radium isotopes, Biogeochemistry, 97, 211229, 2010.

Giacobbe, M. G., Penna, A., Gangemi, E., Masó, M., Garcés, E., Fraga, S., Bravo, I., Azzaro, F., and Penna, N.: Recurrent highbiomass blooms of Alexandrium taylorii (Dinophyceae), a HAB species expanding in the Mediterranean, Hydrobiologia, 580, 125-133, 2007.

Giblin, A. E. and Gaines, A. G.: Nitrogen inputs to a marine embayment: the importance of groundwater, Biogeochemistry, 10, 309-328, 1990.

Gobler, C. J. and Sañudo-Wilhelmy, S. A.: Temporal variability of groundwater seepage and brown tide blooms in a Long Island embayment, Mar. Ecol-Prog. Ser., 217, 299-309, 2001.

Grasshoff, K., Kremling, K., and Ehrhardt, M.: Methods of Seawater Analysis. Chapter 4: determination of nutrients, Weinheim, Germany, 1999.

Heiskanen, A. S., Tamminen, T., and Gundersen, K.: Impact of planktonic food web structure on nutrient retention and loss from a late summer pelagic system in the coastal northern Baltic Sea, Mar. Ecol-Prog. Ser., 145(1-3), 195-208, 1996.

Honsell, G., Nichetto, P., Sidari, L., and Tubaro, A.: Toxic dinoflagellates in the Mediterranean Sea, Giornale Botanico Italiano, 129, 391-403, 1995.

Hwang, D. W., Kim, G., Lee, Y. W., and Yang, H. S.: Estimating submarine inputs of groundwater and nutrients to a coastal bay using radium isotopes, Mar. Chem., 96, 61-71, 2005a.

Hwang, D. W., Lee, Y. W., and Kim, G.: Large submarine groundwater discharge and benthic eutrophication in Bangdu Bay on volcanic Jeju Island, Korea, Limnol. Oceanogr., 50(5), 13931403, 2005b.

IGME: Las aguas subterráneas en la Comunidad Valenciana, Uso, calidad y perspectivas de utilización, Colección Informe, Madrid, 42-46, 1988.

IGME-IRYDA: Informe no 4 Hidrogeología del Sistema no 55: Sistema Acuífero de Javalambre y Sistema Acuífero del Maestrazgo. Proyecto de investigación hidrogeológica de la cuenca media y baja del Júcar, 44-50 (Report no 4 Hydrogeology of the no 55 groundwater system: Javalambre and Maestrazgo, Aquifer Systems Hydrogeological research project of the Jucar river medium and lower basin), 1977 (in Spanish).

Johannes, R. E.: The ecological significance of the submarine discharge of groundwater, Mar. Ecol-Prog. Ser., 3, 365-373, 1980.

Justic, D., Rabalais, N. N., Turner, and R. E.: Stoichiometric nutrient balance and origin of coastal eutrophication, Mar. Pollut. Bull., 30(1), 41-46, 1995.

Kinney, E. H. and Roman, C. T.: The response of primary producers to nutrient enrichment in a shallow estuary, Mar. Ecol-Prog. Ser., 162, 89-98, 1998.

Knee, K. L., Street, J. H., Grossman, E. E., Boehm, A. B., and Paytan, A.: Nutrient inputs to the coastal ocean from submarine groundwater discharge in a groundwater-dominated system: relation to land use (Kona coast, Hawaii, USA), Limnol. Oceanogr., 55(3), 1105-1122, 2010.

Kohout, F. A.: Cyclic flow of salt water in the Biscayne Aquifer of Southeastern Florida, J. Geophys. Res., 65, 2133-2141, 1960.

Krom, M. D., Kress, N., Brenner, S., and Gordon, L. I.: Phosphorus limitation of primary productivity in the eastern Mediterranean Sea, Limnol. Oceanogr., 36(3), 424-432, 1991. 
Laroche, J., Nuzzi, R., Waters, R., Wyman, K., Falkowski, P. G., and Wallace, D. W. R.: Brown tide blooms in Long Island's coastal waters linked to interannual variability in groundwater flow, Glob. Change Biol., 3, 397-410, 1997.

Lee, D. R.: A device for measuring seepage flux in lakes and estuaries, Limnol. Oceanogr., 22, 140-147, 1977.

Mahoney, J. B.: Algal assay of relative abundance of phytoplankton nutrients in northeast United States coastal and shelf waters, Water Res., 23(5), 603-615, 1989.

McClelland, J. W., Valiela, I., and Michener, R. H.: Nitrogen-stable isotope signatures in estuaries food webs: a record of increasing urbanization in coastal watersheds, Limnol. Oceanogr., 42, 930937, 1997.

Mejías, M., Garcia-Orellana, J., Plata, J. L., Marina, M., GarciaSolsona, E., Ballesteros, B., Masqué, P., López, J., and Fernández-Arrojo, C.: Methodology of hydrogeological characterization of deep carbonate aquifers as potential reservoirs of groundwater, Case of study: the Jurassic aquifer of El Maestrazgo (Castellón, Spain), Environ. Geol., 54(3), 521-536, 2008.

Michael, H. A., Mulligan, A. E., and Harvey, C. F.: Seasonal oscillations in water exchange between aquifers and the coastal ocean, Nature, 436(7054), 1145-1148, 2005.

Mijatovic, B.: The groundwater discharge in the Mediterranean karst coastal zones and freshwater tapping: set problems and adopted solutions, Case studies, Environ. Geol., 51, 737-742, 2007.

Moe, M. A.: The Marine Aquarium Handbook: Beginner to Breeder, Norns Publishing Company, 1st. edition, 1982.

Moore, W. S.: Sampling ${ }^{228} \mathrm{Ra}$ in the deep ocean, Deep-Sea Res., 23, 647-651, 1976.

Moore, W. S.: Large groundwater inputs to coastal waters revealed by ${ }^{226} \mathrm{Ra}$ enrichments, Nature 380, 612-614, 1996.

Moore, W. S.: Ages of continental shelf waters determined from ${ }^{223} \mathrm{Ra}$ and ${ }^{224} \mathrm{Ra}$, J. Geophys. Res., 105, 117-122, 2000.

Moore, W.S.: Radium isotopes as tracers of submarine groundwater discharge in Sicily, Cont. Shelf Res., 26(7), 852-861, 2006a.

Moore, W. S.: The role of submarine groundwater discharge in coastal biogeochemistry, J. Geochem. Explor., 88, 389-393, $2006 b$.

Moore, W. S. and Arnold R.: Measurement of Ra-223 and Ra-224 in coastal waters using a delayed coincidence counter, J. Geophys. Res-Oceans 101(C1), 1321-1329, 1996.

Nixon, S. M. and Pilson, M. E. Q.: Nitrogen in estuaries and coastal marine ecosystems, in: Nitrogen in the Marine Environment, edited by: Carpenter E. J. and Capone, D. G., New York, Academic Press, 1983.

Paytan, A., Shellenbarger, G. G., Street, J. H., Gonneea, M. E., Davis, K., Young, M. B., and Moore, W. S.: Submarine groundwater discharge: an important source of new inorganic nitrogen to coral reef ecosystems, Limnol. Oceanogr., 51(1), 343-348, 2006.

Peterson, R. N., Burnett, W. C., Glenn, C. R., and Johnson, A. G.: Quantification of point-source groundwater discharges to the ocean from the shoreline of the Big Island, Hawaii, Limnol. Oceanogr., 54(3), 890-904, 2009.

Price, R. M. and Herman, J. S.: Geochemical investigation of saltwater intrusion into a coastal carbonate aquifer: Mallorca, Spain, Geol. Soc. Am. Bull., 103, 1270-1279, 1991.

Segura, M.: Relació entre la distribució de nutrients i oxígen dis- solt i la composició elemental del fitoplàncton a la Mar Catalana (N - O Mar Mediterrània), Ph.D. thesis, Barcelona, Institut de Ciències del Mar, 2007.

Serrano, V., Roca, A., Pérez, A., Nieto, M., Ortiz, S., and Capilla, J.: Estudio de investigación de las descargas de agua subterránea al mar por la Sierra de Irta (U.H. 08.07: Maestrazgo). Mancomunidad del Baix-Maestrat, Castellón [Research study of groundwater discharges to the sea through the Irta mountains (U.H. 08.07: Maestrazgo), Mancomunidad del Baix-Maestrat, Castellón. In Proceedings of the 6th Hydrogeology Symposium, Seville, Spanish Association of Underground Hydrology, 1995.

Sewell, P. L.: Urban groundwater as a possible nutrient source for an estuarine benthic algal bloom, Estuar. Coast. Shelf S., 15, 569-576, 1982.

Short, F. T. and Burdick D. M.: Quantifying eelgrass habitat loss in relation to housing development and nitrogen loading in Waquoit Bay, Massachusetts, Estuaries, 19, 730-739, 1996.

Slomp, C. P. and Van Cappellen, P.: Nutrient inputs to the coastal ocean through submarine groundwater discharge: controls and potential impact, J. Hydrol., 295(1-4), 64-86, 2004.

Smith, C. G., Cable, J. E., Martin, J. B., and Roy, M.: Evaluating the source and seasonality of submarine groundwater discharge using a radon-222 pore water transport model, Earth Planet. Sc. Lett., 273(3-4), 312-322, 2008.

Swarzenski, P. W., Burnett, W. C., Greenwood, W. J., Herut, B., Peterson, R., Dimova, N., Shalem, Y., Yechieli, Y., and Weinstein, Y.: Combined time-series resistivity and geochemical tracer techniques to examine submarine groundwater discharge at Dor Beach, Israel, Geophys. Res. Lett., 33, L24405, doi:10.1029/2006GL028282, 2006.

Tapia González, F. U., Herrera-Silveira, J. A., and Aguirre-Macedo, M. L.: Water quality variability and eutrophic trends in karstic tropical coastal lagoons of the Yucatán Peninsula, Estuar. Coast. Shelf S., 76, 418-430, 2008.

Uchiyama, Y., Nadaoka, K., Rölke, P., Adachi, K., and Yagi, H.: Submarine groundwater discharge into the sea and associated nutrient transport in a sandy beach, Water Resour. Res., 36(6), 1467-1479, 2000.

UNESCO: Submarine groundwater discharge, Management implications, measurements and effects, Paris, United Nations Educational, Scientific and Cultural Organization IHP-VI, Series on Groundwater, 5, 2004.

Valiela, I., Foreman, K. Lamontagne, M., Hersh, D., Costa, J., Peckol, P., Demeo-Anderson, B., D'avanzp, C., Babione, M., Sham, C., Brawley, J., and Lajtha, K.: Couplings of Watersheds and Coastal Waters: Sources and Consequences of Nutrient Enrichment in Waquoit Bay, Massachusetts, Estuaries, 15(4), 443457, 1992.

Vila, M., Garcés, E., Masó, M., and Camp, J.: Is the distribution of the toxic dinoflagellate Alexandrium catenella expanding along the NW Mediterranean coast?, Mar. Ecol-Prog. Ser., 222, 73-83, 2001.

Young, M. B., Gonneea, M. E., Fong, D. A., Moore, W. S., HerreraSilveira, J., and Paytan, A.: Characterizing sources of groundwater to a tropical coastal lagoon in a karstic area using radium isotopes and water chemistry, Mar. Chem., 109(3-4), 377-394, 2008. 